\title{
Role of the $\mathrm{NO}_{3}$ radicals in oxidation processes in the eastern Mediterranean troposphere during the MINOS campaign
}

\author{
M. Vrekoussis ${ }^{1}$, M. Kanakidou ${ }^{1}$, N. Mihalopoulos ${ }^{1}$, P. J. Crutzen ${ }^{2}$, J. Lelieveld ${ }^{2}$, D. Perner ${ }^{2}$, H. Berresheim ${ }^{3}$, and \\ E. Baboukas ${ }^{2}$ \\ ${ }^{1}$ Environmental Chemical Processes Laboratory, Department of Chemistry, University of Crete, P.O. Box 1470, 71409 \\ Heraklion, Greece \\ ${ }^{2}$ Max-Planck-Institute for Chemistry, Air Chemistry Department, P.O. Box 3060, 55020 Mainz, Germany \\ ${ }^{3}$ German Weather Service, Meteorological Observatory, Hohenpeissenberg, Albin-Schwaiger-Weg 10, Germany
}

Received: 26 March 2003 - Published in Atmos. Chem. Phys. Discuss.: 19 June 2003

Revised: 27 September 2003 - Accepted: 21 January 2004 - Published: 3 February 2004

\begin{abstract}
During the MINOS campaign (28 July-18 August 2001) the nitrate $\left(\mathrm{NO}_{3}\right)$ radical was measured at Finokalia station, on the north coast of Crete in South-East Europe using a long path $(10.4 \mathrm{~km})$ Differential Optical Absorption Spectroscopy instrument (DOAS). Hydroxyl $(\mathrm{OH})$ radical was also measured by a Chemical Ionization MassSpectrometer (Berresheim et al., 2003). These datasets represent the first simultaneous measurements of $\mathrm{OH}$ and $\mathrm{NO}_{3}$ radicals in the area. $\mathrm{NO}_{3}$ radical concentrations ranged from less than $3 \times 10^{7}$ up to $9 \times 10^{8}$ radicals $\mathrm{cm}^{-3}$ with an average nighttime value of $1.1 \times 10^{8}$ radicals $\mathrm{cm}^{-3}$.

The observed $\mathrm{NO}_{3}$ mixing ratios are analyzed on the basis of the corresponding meteorological data and the volatile organic compound (VOC) observations which were measured simultaneously at Finokalia station. The importance of the $\mathrm{NO}_{3}$ radical chemistry relatively to that of $\mathrm{OH}$ in the dimethylsulfide (DMS) and nitrate cycles is also investigated. The observed $\mathrm{NO}_{3}$ levels regulate the nighttime variation of DMS. The loss of DMS by $\mathrm{NO}_{3}$ during night is about $75 \%$ of that by $\mathrm{OH}$ radical during day. $\mathrm{NO}_{3}$ and nitrogen pentoxide $\left(\mathrm{N}_{2} \mathrm{O}_{5}\right)$ reactions account for about $21 \%$ of the total nitrate $\left(\mathrm{HNO}_{3(\mathrm{~g})}+\mathrm{NO}_{3(\mathrm{~g})}^{-}\right)$production.
\end{abstract}

\section{Introduction}

The quality of the air and climate depend on the emissions, chemical transformation and deposition of trace constituents in the atmosphere. The self-cleaning efficiency of the troposphere is important to conserve air quality both during day and night. The most important oxidant species that regu-

Correspondence to: M. Kanakidou

(mariak@chemistry.uoc.gr) late the self-cleaning efficiency of the troposphere are the $\mathrm{OH}$ radical, the $\mathrm{NO}_{3}$ radical and ozone.

During the day, $\mathrm{OH}$ plays a decisive role in the cleaning mechanism of the atmosphere. During the night its concentration is, in most situations, negligible, thus, $\mathrm{NO}_{3}$ radicals and $\mathrm{O}_{3}$ are the main oxidants (e.g. Platt et al., 1984; Wayne et al., 1991; Poisson et al., 2001). $\mathrm{NO}_{3}$ reacts with a number of VOCs initiating their night time degradation (Atkinson et al., 2000). It also contributes to the removal of $\mathrm{NO}_{\mathrm{x}}$ (Allan et al., 1999) mainly via nitric acid $\left(\mathrm{HNO}_{3}\right)$ and particulate nitrate formation.

Regardless their importance, measurements of $\mathrm{OH}$ and $\mathrm{NO}_{3}$ are scarce as they have been proven difficult due to the very low concentrations and the high spatial and temporal variability of these radicals. However, the DOAS measurements average over a few minutes of time and a few kilometres of distance (see Sect. 2.1) and thus partially integrate the time and space variability of the radical. The relative contribution of these two radicals to the oxidation efficiency of the atmosphere requires further investigation.

The major source of $\mathrm{NO}_{3}$ is the oxidation of nitrogen dioxide $\left(\mathrm{NO}_{2}\right)$ by ozone $\left(\mathrm{O}_{3}\right)$ :

$\mathrm{NO}_{2}+\mathrm{O}_{3} \longrightarrow \mathrm{NO}_{3}+\mathrm{O}_{2}$

The production rate of $\mathrm{NO}_{3}\left(P_{\mathrm{NO}_{3}}\right)$ by this reaction is given by $P_{\mathrm{NO}_{3}}=k_{\mathrm{NO}_{2}+\mathrm{O}_{3}} \cdot\left[\mathrm{NO}_{2}\right] \cdot\left[\mathrm{O}_{3}\right]$ and equals $0.072 \mathrm{ppbv}$ $\mathrm{NO}_{3}$ per hour, for $0.5 \mathrm{ppbv}$ of $\mathrm{NO}_{2}$ and $50 \mathrm{ppbv}$ of $\mathrm{O}_{3}$ at $298 \mathrm{~K}$, conditions typical of the Mediterranean area during summertime.

During the day, $\mathrm{NO}_{3}$ has a very short lifetime (about $5 \mathrm{~s}$ ) due to its strong absorption in the visible region of the solar spectrum (maximum absorption at $662 \mathrm{~nm}$ ) and its rapid 


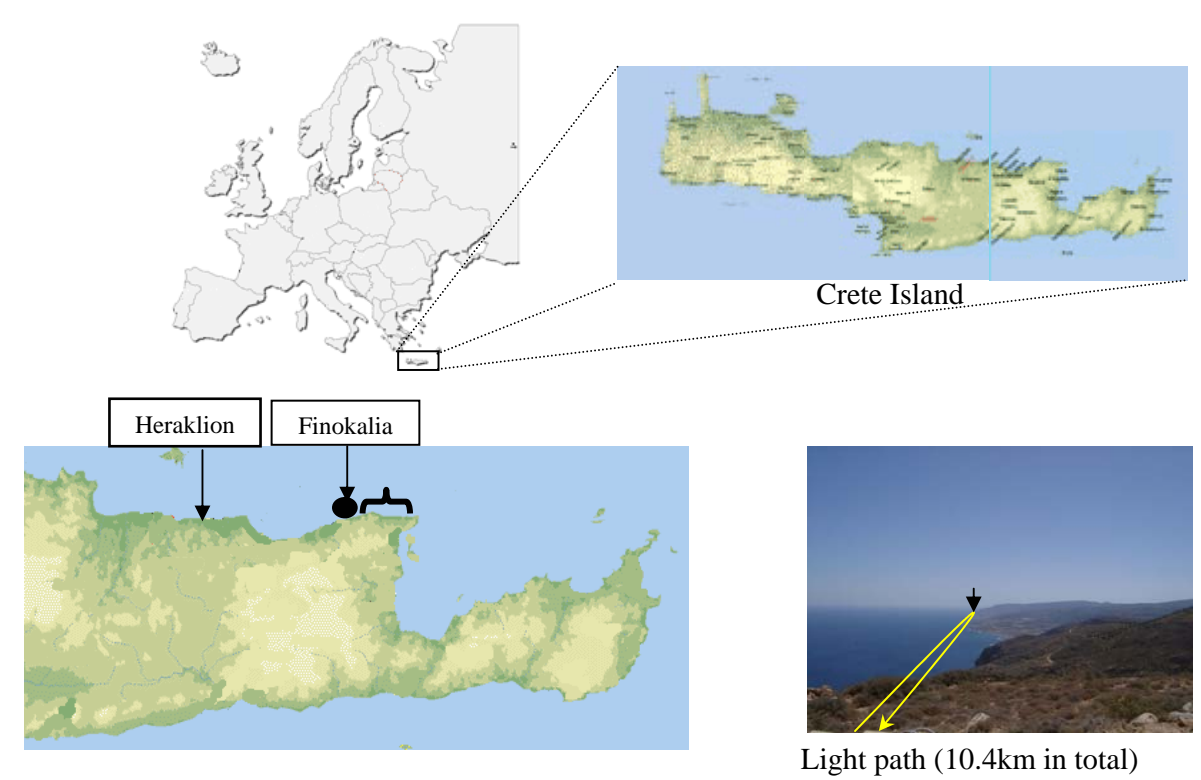

Fig. 1. Location of the Finokalia station, the retroreflectors and an indication of the light path of the DOAS instrument during the experiment.

photodissociation, mainly to $\mathrm{NO}_{2}$ (Reaction 2a) and to a lesser extent to NO (Reaction 2b):

$$
\begin{aligned}
& \mathrm{NO}_{3}+\mathrm{h} v \longrightarrow \mathrm{NO}_{2}+\mathrm{O}\left({ }^{3} \mathrm{P}\right) \\
& \mathrm{NO}_{3}+\mathrm{h} v \longrightarrow \mathrm{NO}+\mathrm{O}_{2}
\end{aligned}
$$

In mid-latitudes near the surface the combined photolysis rate of the Reactions (2a) and (2b) is about $J_{2}=0.2 \mathrm{~s}^{-1}=720 \mathrm{~h}^{-1}$ at noon during summer. Assuming dynamic equilibrium of $\mathrm{NO}_{3}$ (production by Reaction (1) equals loss by photo-dissociation ( $2 \mathrm{a}$ and $2 \mathrm{~b}$ )), the daytime concentration of $\mathrm{NO}_{3}$ is calculated to be $0.1 \mathrm{pptv}$ $\left(\mathrm{PNO}_{3} / J_{2}=\left[72 \mathrm{pptv} \mathrm{h}^{-1}\right] /\left[720 \mathrm{~h}^{-1}\right]\right)$. Such low $\mathrm{NO}_{3}$ levels cannot be detected by the DOAS instrument as will be discussed later.

In the presence of $\mathrm{NO}, \mathrm{NO}_{3}$ is rapidly converted to $\mathrm{NO}_{2}$ via Reaction (3). At $298 \mathrm{~K}$ and for a NO concentration of about 0.3 ppbv, the Reaction (3) is equivalent to the $\mathrm{NO}_{3}$ loss via photo dissociation $J_{2}$ in mid latitudes at noon:

$\mathrm{NO}+\mathrm{NO}_{3} \longrightarrow 2 \mathrm{NO}_{2}$

$\mathrm{NO}_{3}$ reacts with $\mathrm{NO}_{2}$ to produce $\mathrm{N}_{2} \mathrm{O}_{5}$ via the temperaturedependent equilibrium (Waengberg et al., 1997):

$\mathrm{NO}_{3}+\mathrm{NO}_{2}+M \rightleftharpoons \mathrm{N}_{2} \mathrm{O}_{5}+\mathrm{M}$

Subsequent removal of nitrogen pentoxide $\left(\mathrm{N}_{2} \mathrm{O}_{5}\right)$ leads to a net loss of $\mathrm{NO}_{3}$ from the atmosphere. In the gas phase $\mathrm{N}_{2} \mathrm{O}_{5}$ can contribute to nitric acid formation following first and second order reactions with water vapour (Wahner et al., 1998; Atkinson et al., 2003; http://www.iupac-kinetic.ch.cam.ac. $\mathrm{uk} /)$ :

$\mathrm{N}_{2} \mathrm{O}_{5}+\mathrm{H}_{2} \mathrm{O} \rightarrow 2 \mathrm{HNO}_{3}$
$\mathrm{N}_{2} \mathrm{O}_{5}+2 \mathrm{H}_{2} \mathrm{O} \longrightarrow 2 \mathrm{HNO}_{3}+\mathrm{H}_{2} \mathrm{O}$

The rates of the above reactions remain rather uncertain since the temperature dependence of these rates is not satisfactorily documented (Dimitroulopoulou and Marsh, 1997). Thus, the Wahner et al. (1998) temperature independent estimates, which are recommended by Atkinson et al. (2002), are used in the present study. Note also that Sander et al. (2003; JPL recommendations) give a slightly higher upper limit of $2 \times 10^{-21}$ for the first order Reaction (5a). They also point out the large difficulty in distinguishing between the gas phase and the heterogeneous reactions of $\mathrm{N}_{2} \mathrm{O}_{5}$ with water and mention that the rate of (5a) could be 4 times lower, as has been measured by Sverdrup et al. (1987). This fourfold uncertainty is taken into account in the following discussion.

Additional $\mathrm{HNO}_{3}$ formation paths involve VOC reactions with $\mathrm{NO}_{3}$ and particularly DMS, aldehydes and higher alkanes (through the $\mathrm{H}$ abstraction mechanism) as well as heterogeneous reactions of $\mathrm{NO}_{3}$ or $\mathrm{N}_{2} \mathrm{O}_{5}$ on particles (Heintz et al., 1996). The $\mathrm{NO}_{3}$ reaction with unsaturated VOC proceeds via addition of $\mathrm{NO}_{3}$ to the double $\mathrm{C}$ bond and does not produce $\mathrm{HNO}_{3}$.

Several authors reported important interactions between nitrogen and sulfur cycles in the marine atmosphere via the $\mathrm{NO}_{3}$ radical (Yvon et al., 1996; Carslaw et al., 1997; Allan et al., 1999; 2000). For instance, Allan et al. (1999) calculated that at $\mathrm{NO}_{\mathrm{x}}$ levels exceeding 100 pptv, conditions typical of the marine atmosphere in the Northern Hemisphere, $\mathrm{OH}$ and $\mathrm{NO}_{3}$ radicals are expected to equally contribute to the loss of DMS. The $\mathrm{NO}_{3}$ radical contributes also to $\mathrm{HNO}_{3}$ production during night as was shown by several studies including Heintz et al. (1996), Mentel et al. (1996), Allan et al. (2000), Geyer and Platt (2002). 


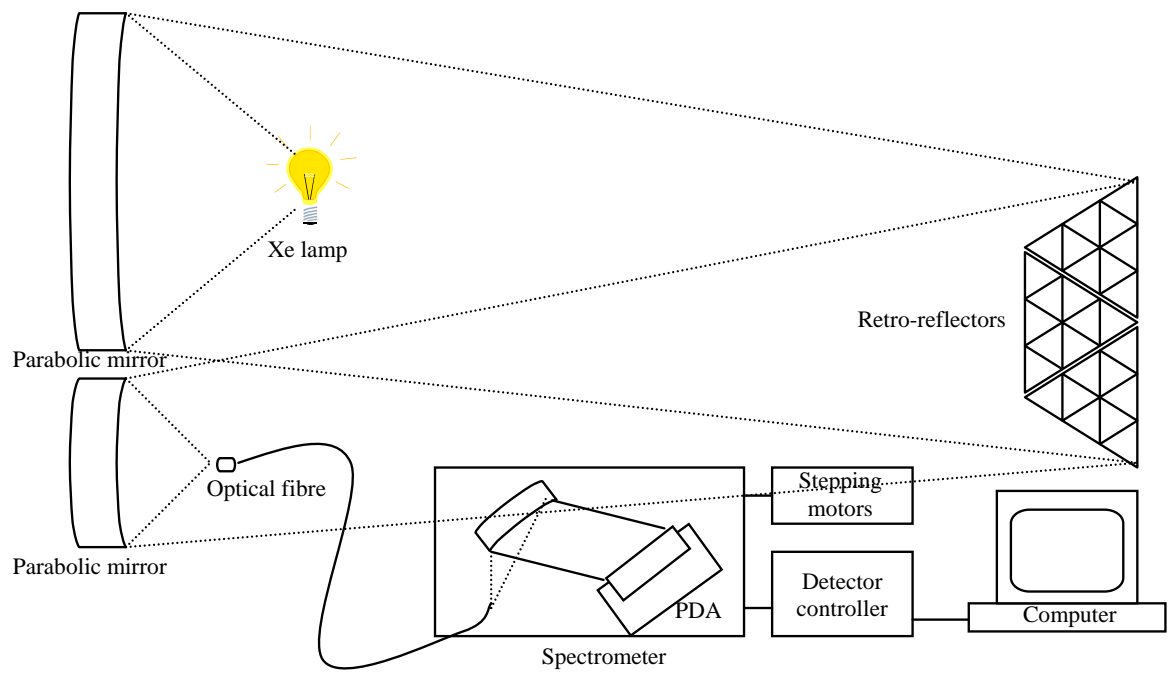

Fig. 2. Sketch of the long path DOAS system.

As part of the MINOS experiment daily measurements of ambient $\mathrm{NO}_{3}$ concentrations were conducted during summer 2001, at the ground level station at Finokalia on the northeastern coast of Crete. The aim was to study the $\mathrm{NO}_{3}$ occurrence in the Mediterranean marine boundary layer, to evaluate the $\mathrm{NO}_{3}$ role in the oxidation efficiency of the atmosphere and provide insights in the interactions between $\mathrm{S}$ and $\mathrm{N}$ cycles. To achieve these goals simultaneous measurements of $\mathrm{OH}, \mathrm{DMS}, \mathrm{NO}_{2}$, gaseous $\mathrm{HNO}_{3}$ and particulate $\mathrm{NO}_{3}$ have been performed during a one month period.

\section{Experimental}

\subsection{Setup of the long path DOAS instrument}

The $\mathrm{NO}_{3}$ radical mixing ratio has been monitored continuously by using a long path DOAS instrument at Finokalia $\left(35.3^{\prime} \mathrm{N}, 25.3^{\prime} \mathrm{E}\right)$, Crete, Greece, $150 \mathrm{~m}$ above sea level, from 28 July to 18 August 2001 (Fig. 1). The monitoring station of the University of Crete at Finokalia is located $70 \mathrm{~km}$ eastward of Heraklion (137000 inhabitants) and $25 \mathrm{~km}$ west of Agios Nikolaos (19000 inhabitants), the nearest big towns in the area. These towns do not have any noticeable influence on the site due to the prevailing north winds.

The DOAS instrument used during MINOS was provided by the Max-Plank-Institute for Chemistry in Mainz and has been used in the past in several campaigns. The details of its operation have been presented elsewhere (Martinez et al., 2000); here only a short description is given. The DOAS uses a parabolic mirror behind a Xenon high pressure lamp (supplied by Hanovia, $500 \mathrm{~W}$ ) to produce a parallel light beam (Fig. 2). At a distance of $5.2 \mathrm{~km}$, an array of 30 retro-reflectors of $5 \mathrm{~cm}$ diameter reflects the main beam backwards to the sending point (total light path is
$10.4 \mathrm{~km}$ ) where another parabolic mirror focuses the light to the optical fibre in front of the collecting mirror. The reflectors are located near the sea surface (about $10 \mathrm{~m}$ asl) so the DOAS measurements correspond to average concentrations within the first $150 \mathrm{~m}$ a.s.l. Through an optical fibre (inner diameter $600 \mu \mathrm{m}$ ) the light is transmitted to the spectrograph and then to the detector. The spectrograph is based on a holographic lattice of the Fa. American Holographic (455.01, 240-800 nm) with a focal length of $212 \mathrm{~mm}$, a linear dispersion of $7 \mathrm{~nm} \mathrm{~mm}^{-1}$ and a diffraction grating with 550 grooves $\mathrm{mm}^{-1}$. The detector used to record the data is a 1024 pixel photodiode array (PDA, RY-1024, Hamamatsu), fixed to the focal plane of the spectrograph and cooled to $-20^{\circ} \mathrm{C}$ to minimize the dark current.

The spectrum $(\mathrm{N})$ used for the calculation of the species of interest has been obtained using the following equation:

$\mathrm{N}=\frac{M-S}{L-O}$

where:

- $\mathrm{M}$ is the atmospheric spectrum measured when the light path is focused on the centre of the fibre and contains scattered light,

- $\mathrm{S}$ is a spectrum of the atmospheric background due to scattered light measured by mechanically shifting the focus of the collecting mirror about $1 \mathrm{~cm}$ away from the optical fibre,

- $\mathrm{O}$ is the offset measured when the fibre is lidded by a black cover,

- $\mathrm{L}$ is the Lamp spectrum measured when the fibre is mounted directly to the lamp. 


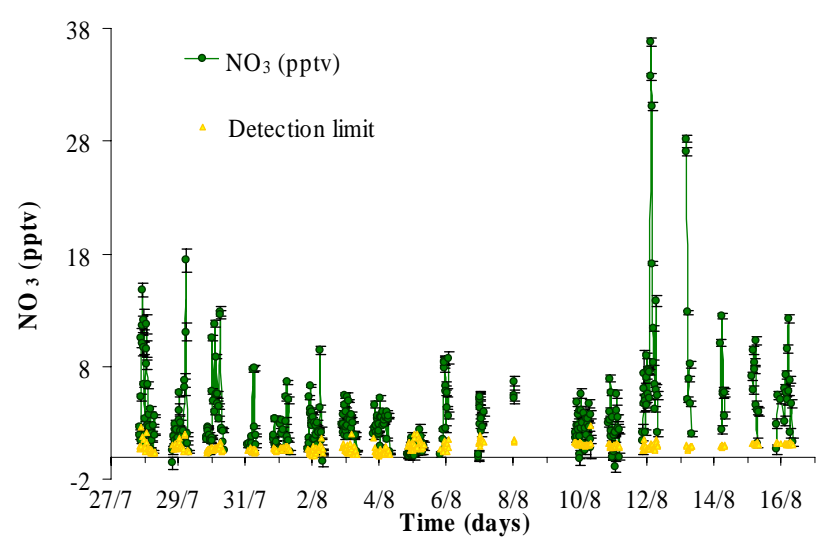

Fig. 3. $\mathrm{NO}_{3}$ time series (in pptv) obtained at Finokalia during the MINOS campaign.

Note that after each $\mathrm{S}$ spectrum measurement the light is refocused on the focal point using an optimisation procedure that is computer controlled. Since a S spectrum is taken before each individual measurement, several $\mathrm{S}$ spectra are used for an integrated 30-min averaged measurement.

The $\mathrm{N}$ spectrum is then smoothed by fast Fourier transform, firstly with a high pass frequency filter and secondly, with a low pass frequency filter in order to remove i) highfrequency noise from the variability of the diode arrays, ii) adjacent broader spectral trends caused by Rayleigh and Mie scattering in the atmosphere and iii) detector etaloning. Every measurement is the mean value of nineteen individual ones and, on average, lasted 30 minutes.

The method used to obtain the final spectrum containing the information for the species of interest is the multi-scanning technique described in detail by MartinezHarder (1998) and Brauers et al. (1995).

The $\mathrm{NO}_{3}$ radical is detected in the visible spectral range. Two absorption peaks have been identified in the red region at 662 and $623 \mathrm{~nm}$. In this work both $\mathrm{NO}_{3}$ absorption bands are used for the $\mathrm{NO}_{3}$ evaluation procedure and the band $\left(B_{2} E^{\prime}-X^{2} A_{2}^{\prime}\right)$ at $662 \mathrm{~nm}$ is used for the quantification. Apart from the $\mathrm{NO}_{3}$ radical, the main absorbers in that region (620-670) $\mathrm{nm}$ are water vapour and $\mathrm{NO}_{2}$, and these species are fitted along with $\mathrm{NO}_{3}$ in the analysis routine. The influence of water is much more critical for $\mathrm{NO}_{3}$ than that of $\mathrm{NO}_{2}$ because overtone vibrational bands of water peak at $651.5 \mathrm{~nm}$, very close to $\mathrm{NO}_{3}$. Since the concentration of $\mathrm{NO}_{3}$ during daytime is negligible due to its rapid photolysis, daytime reference spectra (collected several times per day) are used as references for the humidity in the deconvolution procedure. These reference spectra for $\mathrm{H}_{2} \mathrm{O}$ and $\mathrm{NO}_{2}$ were then fitted simultaneously with the $\mathrm{NO}_{3}$ reference spectrum to derive the $\mathrm{NO}_{3}$ radical signature using a least-squares fitting routine that employs singular value decomposition. The thus derived optical density of this peak and the $\mathrm{NO}_{3}$ cross sec- tions reported by Yokelson et al. (1994) are used to determine $\mathrm{NO}_{3}$ radical concentration. The instrumental noise $(\sigma)$ that determines the detection limit of the method leads to a detection limit $(3 \sigma)$ of $1.2 \mathrm{pptv}$. Note that the few negative $\mathrm{NO}_{3}$ values that have been calculated with this procedure have absolute values that are always below the detection limit of the method. These values are depicted in Fig. 3 that presents $\mathrm{NO}_{3}$ observations by the DOAS instrument integrated approximately every $30 \mathrm{~min}$ during the whole campaign. The negative values are not taken into account for the interpretation and discussion of the results. Missing data were due to power breakdown or to drift of the focal point of the instrument during operation.

Nitrogen dioxide was measured also using the DOAS technique. The procedure is similar as the one described above for the $\mathrm{NO}_{3}$ except that $\mathrm{NO}_{2}$ has also clear peaks in the UV region. $\mathrm{NO}_{2}$ was calculated from its peak at $405 \mathrm{~nm}$ with a cross section of $6.38 \times 10^{-19} \mathrm{~cm}^{2}$ (Yoshino et al, 1997). The mean instrumental noise $(\sigma)$ in the case of $\mathrm{NO}_{2}$ has been estimated to be $80 \mathrm{pptv}$, which leads to a detection limit $(3 \sigma)$ of $240 \mathrm{pptv}$.

\subsection{Ancillary measurements}

DMS was collected into 6-liter stainless steel electropolished canisters and analysed following the procedure described in details by Kouvarakis and Mihalopoulos (2000) and Bardouki et al. (2004). One sample was sampled and analysed per hour and the detection limit was 1 pptv.

Gaseous $\mathrm{HNO}_{3}$ was analysed using the nebulization/reflux (Cofer mist) technique described in Cofer et al. (1985) and Sciare and Mihalopoulos (1999). A $0.5 \mu \mathrm{m}$ PTFE filter was mounted in front of the Cofer line to collect aerosols. Gaseous $\mathrm{HNO}_{3}$ was trapped by the mist and was analyzed as nitrate by Ion Chromatography. Simultaneously the PTFE filter situated in front of the Cofer sampler was extracted with MQ-water and analysed for nitrate using Ion Chromatography. Details on the analytical procedure can be found in Kouvarakis et al. (2000).

The meteorological data was obtained by an automatic meteorological station, which recorded ambient air temperature $(\mathrm{T})$, relative humidity $(\mathrm{RH})$, wind speed, wind direction and the direct solar radiation. The available data during the MINOS related to the $\mathrm{NO}_{3}$ analysis and the corresponding analytical techniques, instruments and detection limits are summarised in Table 1.

\section{Results}

\subsection{Measurements}

The measured temporal profile of the $\mathrm{NO}_{3}$ radical levels from 28 July to 17 August 2001 is shown in Fig. 3 together with the calculated detection limit ( 3 times the noise). A large daily as well as hourly variability of $\mathrm{NO}_{3}$ has been observed, 
Table 1. Measurements during MINOS relevant to the present analysis.

\begin{tabular}{lll}
\hline Measurement & Technique & Detection limit - Time resolution needed \\
\hline $\mathrm{NO}, \mathrm{NO}_{\mathrm{y}}$ & Chemiluminescent detector & $50 \mathrm{pptv}-5 \mathrm{~min}$ \\
$\mathrm{NO}_{2}$ & DOAS & $250 \mathrm{pptv}-15 \mathrm{~min}$ \\
$\mathrm{NO}_{3}$ & DOAS & $1.5 \mathrm{pptv}-30 \mathrm{~min}$ \\
$\mathrm{HNO}_{3}$ & Nebulisation/reflux - IC & $20 \mathrm{pptv}-3 \mathrm{~h}$ \\
$\mathrm{O}_{3}$ & UV photometer & $1 \mathrm{ppbv}-5 \mathrm{~min}$ \\
$\mathrm{DMS}$ & GC-FPD & $1 \mathrm{pptv}-60 \mathrm{~min}$ \\
$\mathrm{OH}$ & Chemical Ionization & \\
& Mass Spectrometry & $2.4 \times 10^{5} \mathrm{rad} / \mathrm{cm}^{3}(2 \sigma)-5 \mathrm{~min}$ \\
T, R.H., wind speed, & Meteorological station & $5 \mathrm{~min}$ \\
wind direction, & & \\
solar irradiance & & $5 \mathrm{~min}$ \\
$\mathrm{~J}\left(\mathrm{NO}_{2}\right), \mathrm{J}\left(\mathrm{O}^{1} \mathrm{D}\right)$ & 2pi radiometer & \\
\hline
\end{tabular}

Table 2. Observations of $\mathrm{NO}_{3}$ radicals in the boundary layer.

\begin{tabular}{ccccccc}
\hline Site & Coordinates & $\mathrm{NO}_{3}$ Average (pptv) & $\mathrm{NO}_{3}$ Maximum (pptv) & Total path (km) & Year (summer) & Ref. \\
\hline Continental Boundary Layer & & & & & & \\
\hline Lindenberg & $52^{\circ} 13^{\prime} \mathrm{N}-14^{\circ} 07^{\prime} \mathrm{E}$ & 4.6 & 85 & 10 & 1998 & Geyer et al., 2001 \\
\hline Marine Boundary Layer & & & & & & \\
\hline Tenerife & $28^{\circ} 40^{\prime} \mathrm{N}-16^{\circ} 05^{\prime} \mathrm{W}$ & 8 & 20 & 9.6 & 1994 & Carslaw et al., 1997 \\
Kap Arkona (Rügen Island) & $54^{\circ} 30^{\prime} \mathrm{N}-13^{\circ} 30^{\prime} \mathrm{E}$ & $6-10$ & 98 & 5 & $1993 / 94$ & Heintz et al., 1996 \\
Wayborne Clean conditions & $52^{\circ} 57^{\prime} \mathrm{N}-1^{\circ} 08^{\prime} \mathrm{E}$ & 6 & - & 1995 & Allan et al., 1999 \\
Mace Head & $53^{\circ} 19^{\prime} \mathrm{N}, 9^{\circ} 54^{\prime} \mathrm{W}$ & 5 & 40 & 8.4 & 1996 & Allan et al., 2000 \\
Finokalia & $35^{\circ} 30^{\prime} \mathrm{N}, 25^{\circ} 7^{\prime} \mathrm{E}$ & 4.5 & 37 & 10.4 & 2001 & This work \\
\hline
\end{tabular}

ranging from values below the detection limit (1.2 pptv) up to 37 pptv. The highest values have been observed during the night of 11 to 12 August 2001. This event will be discussed below. Table 2 presents $\mathrm{NO}_{3}$ radical measurements reported for various locations around the world and compares them with the data obtained during this study. In general, the $\mathrm{NO}_{3}$ observations at Finokalia station appear to be within the range of the reported data for the marine boundary layer.

\subsection{Diurnal variation of $\mathrm{NO}_{3}$}

Daytime $\mathrm{NO}_{3}$ levels were below the detection limit throughout the campaign (Fig. 4). $\mathrm{NO}_{3}$ increases during sunset and reaches up to several tens of pptv during night. It decreases rapidly again during sunrise due to photodissociation. Similar diurnal tendencies have been reported by several authors in coastal areas (Heintz et al., 1998; Allan et al., 1999, 2000).

For comparison, Fig. 4 presents the mean diurnal variation of $\mathrm{OH}$ radicals (blue line) during the campaign. A detailed presentation of the $\mathrm{OH}$ measurements can be found in Berresheim et al. (2003). $\mathrm{OH}$ levels showed a strong diurnal variability with maxima

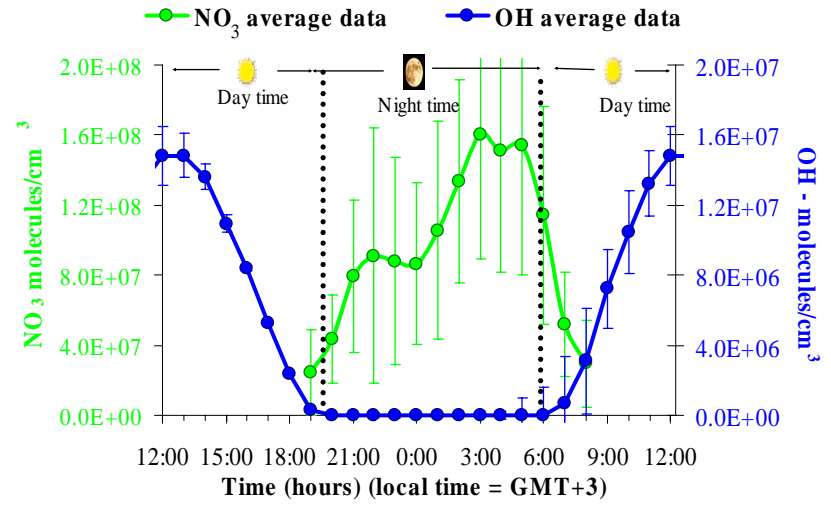

Fig. 4. Mean diurnal profile of the $\mathrm{NO}_{3}$ radical concentration during the MINOS campaign. For comparison, $\mathrm{OH}$ radicals simultaneous measured are also reported. Note the factor of 10 between the two scales.

(approximately $2 \times 10^{7}$ molecules $\mathrm{cm}^{-3}$ ) occurring around 12:30 local time and nighttime values below the detection limit. During the entire $\mathrm{OH}$ measurement period 

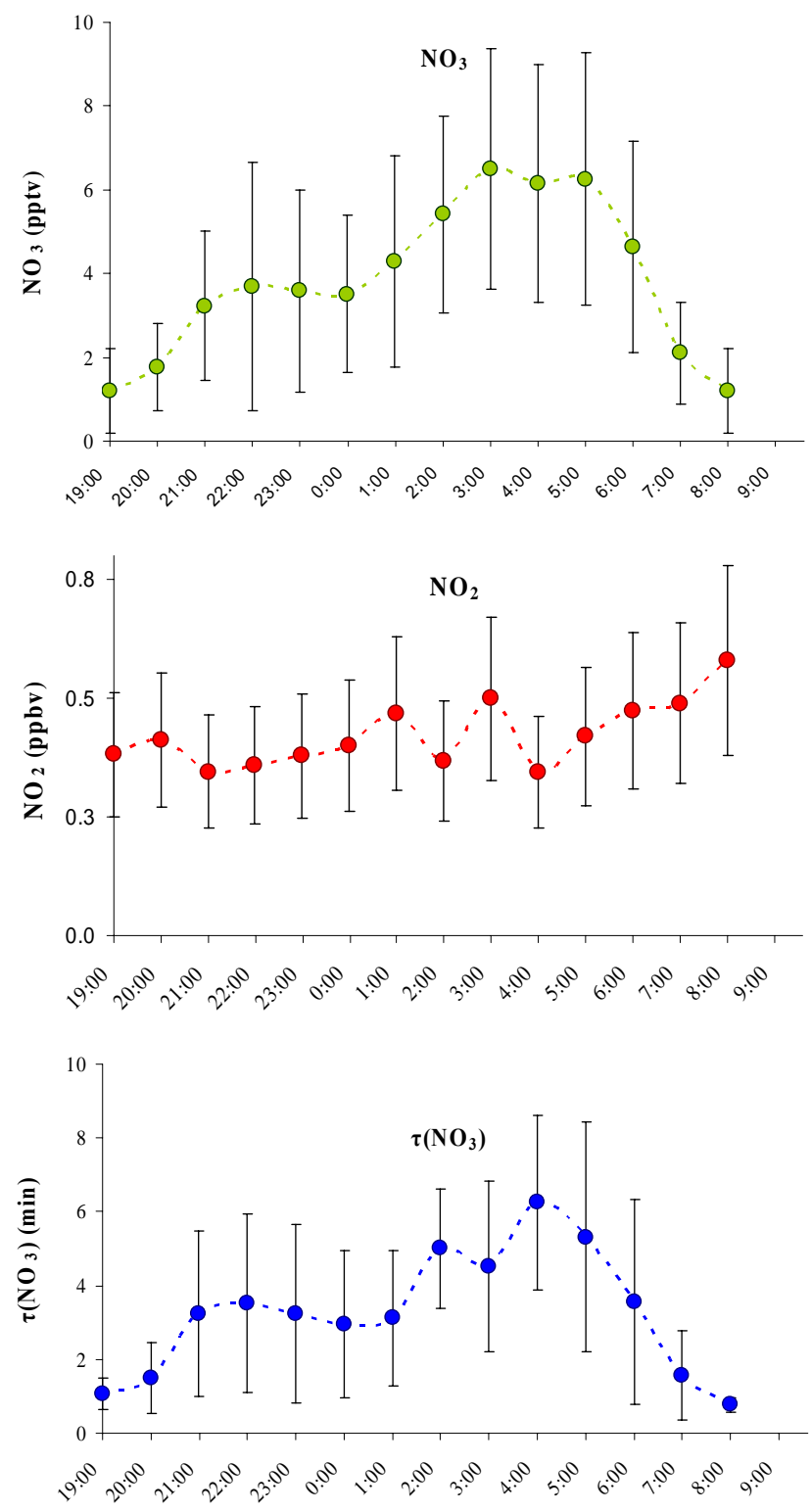

Fig. 5. Hourly mean observations and standard deviation (a) of $\mathrm{NO}_{3}$ in pptv, (b) of $\mathrm{NO}_{2}$ in ppbv and (c) lifetime of $\mathrm{NO}_{3}$ radicals in $\min$ - see text - during the MINOS campaign.

(6-21 August), the daytime mean and standard deviation were $8.2( \pm 1.6) \times 10^{6}$ molecules $\mathrm{cm}^{-3}$, i.e. a factor of 13 lower than the nighttime $\mathrm{NO}_{3}$ levels (1.1 $( \pm 1.1) \times 10^{8}$ molecules $\left.\mathrm{cm}^{-3}\right)$. Most of the reactions of $\mathrm{NO}_{3}$ with VOCs have rate constants that are between 5 and 1000 times slower than the corresponding reactions with $\mathrm{OH}$ (Atkinson et al., 2003, IUPAC recommendations). Thus according to the $\mathrm{NO}_{3}$ and $\mathrm{OH}$ levels observed during this study the destruction rates of some VOCs are more important during the night than during daytime.

A very useful diagnostic tool for analyzing field observations of $\mathrm{NO}_{3}$ is to calculate the atmospheric lifetime of the
Table 3. Rates constants for the reactions $\left(4, \mathrm{k}_{4}\right)$ and $\left(-4, \mathrm{k}_{-4}\right)$, their ratio $\mathrm{k}_{4} / \mathrm{k}_{-4}$ at the minimum and maximum temperatures observed during MINOS and the corresponding $\mathrm{NO}_{2}$ levels at which the $\mathrm{NO}_{3}$ and the $\mathrm{N}_{2} \mathrm{O}_{5}$ levels are equal. The reported lifetimes have been calculated on the basis of the geometric mean observed $\mathrm{NO}_{2}$ mixing ratio of $0.4 \mathrm{ppbv}$.

\begin{tabular}{lll}
\hline & $\mathrm{T} \min \left(22.5^{\circ} \mathrm{C}\right)$ & $\mathrm{T} \max \left(30.2^{\circ} \mathrm{C}\right)$ \\
\hline $\mathrm{k}_{4}\left(\right.$ molecules $\left.^{-1} \mathrm{~cm}^{3} \mathrm{~s}^{-1}\right)$ & $1.39 \times 10^{-12}$ & $2.02 \times 10^{-12}$ \\
$\mathrm{NO}_{2}+\mathrm{NO}_{3} \rightarrow \mathrm{N}_{2} \mathrm{O}_{5}$ & & \\
$\mathrm{k}_{-4}\left(\mathrm{~s}^{-1}\right)$ & $3.67 \times 10^{-2}$ & $1.66 \times 10^{-1}$ \\
$\mathrm{~N}_{2} \mathrm{O}_{5} \rightarrow \mathrm{NO}_{2}+\mathrm{NO}_{3}$ & & \\
$\mathrm{k}_{4} / \mathrm{k}_{-4}$ & $2.63 \times 10^{10}$ & $8.21 \times 10^{10}$ \\
$\mathrm{NO}_{2}(\mathrm{ppbv})$ for $\mathrm{NO}_{3} / \mathrm{N}_{2} \mathrm{O}_{5}=1$ & 1.07 & 3.35 \\
$\tau_{\mathrm{N}_{2} \mathrm{O}_{5} \mathrm{k}-4}(\mathrm{~s})$ & 27 & 6 \\
$\tau_{\mathrm{NO}_{3}-\mathrm{k} 4}(\mathrm{~s})$ & 92 & 63 \\
\hline
\end{tabular}

radical. As suggested by Platt et al. (1980), when $\mathrm{NO}_{3}$ chemistry is in steady state, its lifetime $\tau\left(\mathrm{NO}_{3}\right)$ is given by:

$\tau\left(\mathrm{NO}_{3}\right)=\left[\mathrm{NO}_{3}\right]_{s s} /\left(\mathrm{K}_{\mathrm{NO}_{2}+\mathrm{O}_{3}}\left[\mathrm{NO}_{2}\right]\left[\mathrm{O}_{3}\right]\right)$

The mean values (with one standard deviation) of $\mathrm{NO}_{3}$ and $\mathrm{NO}_{2}$ observed during the campaign and used to calculate the lifetime $\tau\left(\mathrm{NO}_{3}\right)$ are depicted in Figs. 5a and b. The calculated $\tau\left(\mathrm{NO}_{3}\right)$ during the MINOS campaign is found to range between 1 and $6 \mathrm{~min}$; Fig. 5c. This very short lifetime of $\mathrm{NO}_{3}$ actually supports the steady state assumption and is reproduced by the modelling study presented in Sect. 3.5. The steady state assumption does not exclude that $\mathrm{NO}_{3}$ or $\mathrm{N}_{2} \mathrm{O}_{5}$ are transported to/from the sampling site from/to areas with different air temperatures. Under the experimental conditions $\mathrm{NO}_{3}$ and $\mathrm{N}_{2} \mathrm{O}_{5}$ interconvert very fast to reach equilibrium with levels that depend on temperature and the $\mathrm{NO}_{2}$ concentrations. For the high temperatures occurring during the MINOS experiment and for the geometric mean $\mathrm{NO}_{2}$ levels observed during the MINOS campaign, the turnover times of $\mathrm{NO}_{3}$ and $\mathrm{N}_{2} \mathrm{O}_{5}$ for the Reactions (4) range from 1-1.5 min and from 6-27s respectively (Table 3). With such short turnover times, equilibrium is reached in less than $2 \mathrm{~min}$.

The calculated $\tau\left(\mathrm{NO}_{3}\right)$ is in good agreement with the average of $4.2 \mathrm{~min}$ reported by Heintz et al. (1996) from longterm observations of $\mathrm{NO}_{3}$ at the island of Rügen in the Baltic Sea. The balance between the production and loss of $\mathrm{NO}_{3}$ can also be investigated by correlating $\mathrm{NO}_{3}$ levels with the production rate $\mathrm{P}\left(\mathrm{NO}_{3}\right)$. No significant correlation was observed during the MINOS campaign indicating that the $\mathrm{N}_{2} \mathrm{O}_{5}$ sink is regulating the $\mathrm{NO}_{3}$ levels (Martinez et al., 2000; Heintz et al., 1996). In addition, a good negative correlation has been observed between the calculated $\tau\left(\mathrm{NO}_{3}\right)$ and the $\mathrm{NO}_{2}\left(\tau\left(\mathrm{NO}_{3}\right)=-0.94\left[\mathrm{NO}_{2}\right]+4.42, \mathrm{r}^{2}=0.82\right)$ as in Heintz et al. (1996) indicating that $\mathrm{NO}_{3}$ is mainly removed via transformation to $\mathrm{N}_{2} \mathrm{O}_{5}$ and subsequent loss of $\mathrm{N}_{2} \mathrm{O}_{5}$ by reactions with water vapour and heterogeneous reactions. This conclusion is also supported by the model simulations presented in 

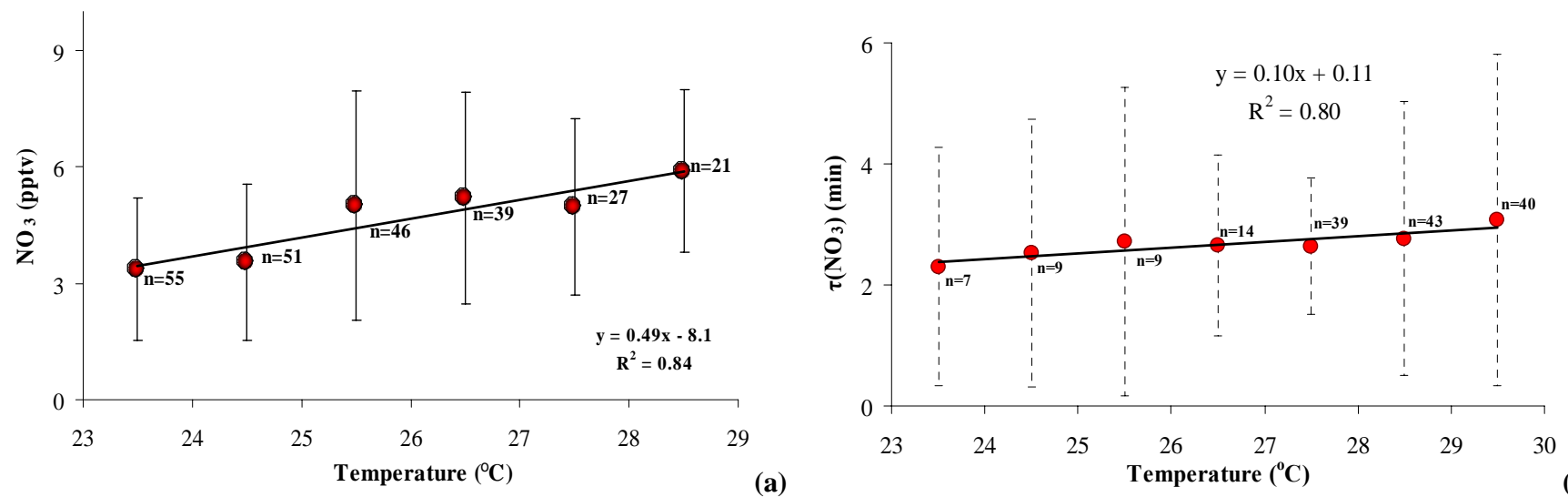

(b)
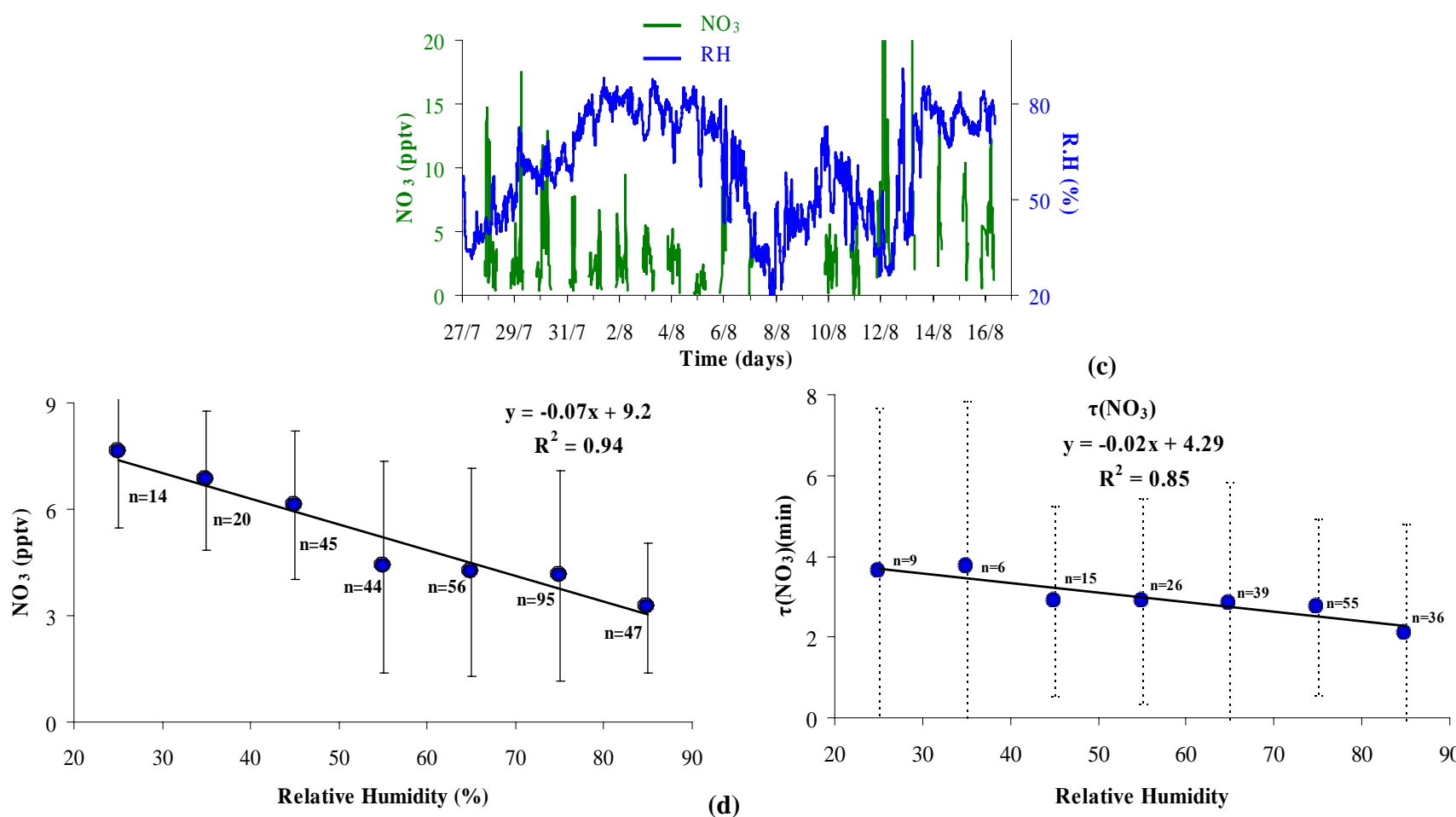

(e)

Fig. 6. (a) correlation between $\mathrm{NO}_{3}$ (in pptv) and air temperature $\left({ }^{\circ} \mathrm{C}\right.$ ) with $\mathrm{NO}_{3}$ values integrated every 10 units of temperature; (b) correlation between $\mathrm{NO}_{3}$ lifetime and air temperature $\left({ }^{\circ} \mathrm{C}\right)$ with values integrated every 10 units of temperature (c) Time series of $\mathrm{NO}_{3}$ and Relative Humidity (RH in \%) during the campaign, (d) correlation between $\mathrm{NO}_{3}$ and $\mathrm{RH}$ with $\mathrm{NO}_{3}$ values integrated every 10 units of RH and (e) correlation between $\mathrm{NO}_{3}$ lifetime and $\mathrm{RH}$.

Sect. 3.5 and by the effect of temperature and relative humidity $(\mathrm{RH})$ on $\mathrm{NO}_{3}$ levels that are discussed in detail in the following paragraphs.

\subsection{Meteorological parameters and their impact on $\mathrm{NO}_{3}$}

Temperature, relative humidity $(\mathrm{RH})$, wind direction and speed and solar radiation were continuously monitored at Finokalia during the MINOS campaign. Temperature ranged between $22.5^{\circ} \mathrm{C}$ and $31.5^{\circ} \mathrm{C}\left(\right.$ mean $\left.=25.7^{\circ} \mathrm{C}\right)$, whereas $\mathrm{RH}$ varied from 20 to $90 \%$ (mean=62\%). The temperature changes observed during MINOS $\left(9^{\circ} \mathrm{C}\right.$ between the maximum and minimum temperature) are expected to affect $\mathrm{NO}_{3}$ variability. Indeed, the rates of the $\mathrm{NO}_{3}$ conversion to $\mathrm{N}_{2} \mathrm{O}_{5}$ (Reaction 4) and of the thermal decomposition of $\mathrm{N}_{2} \mathrm{O}_{5}(\mathrm{Re}-$ action 4$)$ as well as the equilibrium rate $\left(\mathrm{k}_{4} / \mathrm{k}_{-4}\right)$ strongly depend on temperature as shown in Table 3 . On the other hand, for the range of temperatures in Table 3 the production rate of $\mathrm{NO}_{3}$ from the $\mathrm{O}_{3}$ reaction with $\mathrm{NO}_{2}$ presents 2.5-3.5 times smaller temperature dependence (the rate of Reaction (1) is 
Table 4. Gas phase reactions involved in the $\mathrm{NO}_{3}$ radical budget. $\mathrm{T}$ is air temperature in Kelvin, AIR is air density in molecules $\mathrm{cm}^{-3}$ and $\left[\mathrm{O}_{2}\right]$ is $\mathrm{O}_{2}$ concentration in molecules $\mathrm{cm}^{-3}$. The reaction rate of the $\mathrm{OH}$-initiated DMS oxidation is also given for comparison purposes.

\begin{tabular}{|c|c|c|}
\hline Reaction & Rate & Rate at $298 \mathrm{~K}$ \\
\hline \multicolumn{3}{|c|}{$\mathrm{NO}_{3}$ production } \\
\hline $\mathrm{NO}_{2}+\mathrm{O}_{3} \rightarrow \mathrm{NO}_{3}+\mathrm{O}_{2}$ & $1.4 \times 10^{-13} \exp (-2470 / \mathrm{T})$ & $3.55 \times 10^{-17}$ \\
\hline \multicolumn{3}{|c|}{$\mathrm{NO}_{3}$ production from $\mathrm{HNO}_{3}$ loss } \\
\hline \multirow[t]{5}{*}{$\mathrm{HNO}_{3}+\mathrm{OH} \rightarrow \mathrm{NO}_{3}+\mathrm{H}_{2} \mathrm{O}$} & $\mathrm{R}_{1}=2.4 \times 10^{-14} \exp (460 / \mathrm{T})$ & $1.54 \times 10^{-13}$ \\
\hline & $\mathrm{R}_{2}=2.7 \times 10^{-17} \exp (2199 / \mathrm{T})$ & \\
\hline & $\mathrm{R}_{3}=6.5 \times 10^{-34} \exp (1335 / \mathrm{T}) \mathrm{AIR}$ & \\
\hline & $\mathrm{R}=\mathrm{R}_{1}+\mathrm{R}_{3} /\left(1+\mathrm{R}_{3} / \mathrm{R}_{2}\right)$ & \\
\hline & $\mathrm{NO}_{3}$ production from $\mathrm{N}_{2} \mathrm{O}_{5}$ loss & \\
\hline \multirow[t]{3}{*}{$\mathrm{N}_{2} \mathrm{O}_{5}+\mathrm{M} \rightarrow \mathrm{NO}_{2}+\mathrm{NO}_{3}$} & $\mathrm{R}_{1}=10^{-3}(\mathrm{~T} / 300)-3.5 \exp (-11000 / \mathrm{T}) \mathrm{AIR}$ & $5.02 \times 10^{-2}$ \\
\hline & $\mathrm{R}_{2}=9.7 \times 10^{14}(\mathrm{~T} / 300)^{0.1} \exp (-11080 / \mathrm{T})$ & \\
\hline & $\mathrm{F}_{c}=0.35$ & \\
\hline \multicolumn{3}{|l|}{$\mathrm{N}_{2} \mathrm{O}_{5}(\mathrm{~h} v) \rightarrow \mathrm{NO}_{2}+\mathrm{NO}_{3}$} \\
\hline \multicolumn{3}{|c|}{$\mathrm{NO}_{3}$ loss } \\
\hline \multirow[t]{3}{*}{$\mathrm{NO}_{3}+\mathrm{NO}_{2} \rightarrow \mathrm{N}_{2} \mathrm{O}_{5}^{b}$} & $\mathrm{R}_{1}=3.6 \times 10^{-30}(\mathrm{~T} / 300)^{-4.1} \mathrm{AIR}$ & $1.41 \times 10^{-12}$ \\
\hline & $\mathrm{R}_{2}=1.9 \times 10^{-12}(\mathrm{~T} / 300)^{0.2}$ & \\
\hline & $\mathrm{F}_{c}=0.35$ & \\
\hline $\mathrm{NO}_{3}+\mathrm{NO} \rightarrow 2 \mathrm{NO}_{2}$ & $1.8 \times 10^{-11} \exp (110 / \mathrm{T})$ & $2.6 \times 10^{-11}$ \\
\hline $\mathrm{NO}_{3}+\mathrm{NO}_{3} \rightarrow \mathrm{NO}_{2}+\mathrm{NO}_{2}+\mathrm{O}_{2}$ & $8.5 \times 10^{-13} \exp (-2450 / \mathrm{T})$ & $2.3 \times 10^{-16}$ \\
\hline \multicolumn{3}{|l|}{$\mathrm{NO}_{3}(\mathrm{~h} \nu) \rightarrow \mathrm{NO}_{2}+\mathrm{O}$} \\
\hline \multicolumn{3}{|l|}{$\mathrm{NO}_{3}(\mathrm{~h} v) \rightarrow \mathrm{NO}+\mathrm{O}_{2}$} \\
\hline $\mathrm{NO}_{3}+\mathrm{O} \rightarrow \mathrm{NO}_{2}+\mathrm{O}_{2}$ & $1.7 \times 10^{-11}$ & $1.7 \times 10^{-11}$ \\
\hline $\mathrm{NO}_{3} \rightarrow \mathrm{NO}+\mathrm{O}_{2}$ & $1.4 \times 10^{-4}$ & $1.4 \times 10^{-14}$ \\
\hline \multicolumn{3}{|c|}{ Reactions of $\mathrm{NO}_{3}$ with $\mathrm{RO}_{2}$ radicals } \\
\hline $\mathrm{NO}_{3}+\mathrm{HO}_{2} \rightarrow \mathrm{O}_{2}+\mathrm{OH}+\mathrm{O}_{2}$ & $4 . \times 10^{-12}$ & $4.0 \times 10^{-12}$ \\
\hline $\mathrm{NO}_{3}+\mathrm{RO}_{2}{ }^{a} \rightarrow \mathrm{NO}_{2}+\mathrm{HO}_{2}+$ product & $2.3 \times 10^{-12}$ & $2.3 \times 10^{-12}$ \\
\hline \multicolumn{3}{|c|}{ Reactions of $\mathrm{NO}_{3}$ with unsaturated VOC } \\
\hline $\mathrm{NO}_{3}+\mathrm{C}_{2} \mathrm{H}_{4} \rightarrow \mathrm{NO}_{3}$ addition product & $3.3 \times 10^{-12} \exp (-2880 / \mathrm{T})$ & $2.12 \times 10^{-16}$ \\
\hline $\mathrm{NO}_{3}+\mathrm{C}_{3} \mathrm{H}_{6} \rightarrow \mathrm{NO}_{3}$ addition product & $4.6 \times 10^{-13} \exp (-1155 / \mathrm{T})$ & $9.58 \times 10^{-15}$ \\
\hline $\mathrm{NO}_{3}+$ isoprene $\rightarrow$ addition product & $3.03 \times 10^{-12} \exp (-446 / \mathrm{T})$ & $6.79 \times 10^{-13}$ \\
\hline $\mathrm{NO}_{3}+\mathrm{MVK} \rightarrow$ addition product & $4.7 \times 10^{-16}$ & $4.7 \times 10^{-16}$ \\
\hline \multicolumn{3}{|c|}{$\mathrm{HNO}_{3}$ production from $\mathrm{NO}_{3}$ loss } \\
\hline \multicolumn{3}{|c|}{ Reactions of $\mathrm{NO}_{3}$ with aldehydes } \\
\hline $\mathrm{NO}_{3}+\mathrm{HCHO} \rightarrow \mathrm{HNO}_{3}+\mathrm{CO}+\mathrm{HO}_{2}$ & $5.8 \times 10^{-16}$ & $5.8 \times 10^{-16}$ \\
\hline $\mathrm{NO}_{3}+\mathrm{CH}_{3} \mathrm{CHO} \rightarrow \mathrm{HNO}_{3}+\mathrm{RO}_{2}$ & $1.4 \times 10^{-12} \exp (-1900 / \mathrm{T})$ & $2.4 \times 10^{-15}$ \\
\hline $\mathrm{NO}_{3}+\mathrm{MACR} \rightarrow \mathrm{HNO}_{3}+$ product & $3.7 \times 10^{-15}$ & $3.7 \times 10^{-15}$ \\
\hline \multicolumn{3}{|c|}{ Reactions of $\mathrm{NO}_{3}$ with DMS } \\
\hline $\mathrm{NO}_{3}+\mathrm{DMS} \rightarrow \mathrm{HNO}_{3}+$ radical & $1.9 \times 10^{-13} \exp (500 / \mathrm{T})$ & $1.02 \times 10^{-12}$ \\
\hline \multicolumn{3}{|c|}{ DMS reaction with $\mathrm{OH}$ radical (given here for comparison purposes) } \\
\hline $\mathrm{OH}+\mathrm{DMS} \rightarrow$ addition products & $\left.1.7 \times 10^{-42} \exp (7810 / \mathrm{T})\left[\mathrm{O}_{2}\right]\right) /\left(1+5.510^{-31} \exp (7460 / \mathrm{T})\left[\mathrm{O}_{2}\right]\right)$ & $1.8 \times 10^{-12}$ \\
\hline $\mathrm{OH}+\mathrm{DMS} \rightarrow$ abstraction products & $1.13 \times 10^{-11} \exp (-253 / \mathrm{T})$ & $4.8 \times 10^{-12}$ \\
\hline \multicolumn{3}{|c|}{$\mathrm{N}_{2} \mathrm{O}_{5}$ loss to $\mathrm{HNO}_{3}$} \\
\hline $\mathrm{N}_{2} \mathrm{O}_{5}+\mathrm{H}_{2} \mathrm{O} \rightarrow 2 \mathrm{HNO}_{3}$ & $2.5 \times 10^{-22}$ & $2.5 \times 10^{-22}$ \\
\hline $\mathrm{N}_{2} \mathrm{O}_{5}+\mathrm{H}_{2} \mathrm{O}+\mathrm{H}_{2} \mathrm{O} \rightarrow 2 \mathrm{HNO}_{3}+\mathrm{H}_{2} \mathrm{O}$ & $1.8 \times 10^{-39}$ & $1.8 \times 10^{-39}$ \\
\hline \multicolumn{3}{|c|}{ Other $\mathrm{HNO}_{3}$ production } \\
\hline \multirow[t]{3}{*}{$\mathrm{NO}_{2}+\mathrm{OH} \rightarrow \mathrm{HNO}_{3}^{b}$} & $\mathrm{R}_{1}=2.6 \times 10^{-30}(\mathrm{~T} / 300)^{-2.9} \mathrm{AIR}$ & \\
\hline & $\mathrm{R}_{2}=4.1 \times 10^{-11}$ & $1.05 \times 10^{-11}$ \\
\hline & $\mathrm{F}_{c}=0.4$ & \\
\hline \multicolumn{3}{|c|}{ Other $\mathrm{HNO}_{3}$ losses } \\
\hline $\mathrm{HNO}_{3}(\mathrm{~h} v) \rightarrow \mathrm{NO}_{2}+\mathrm{OH}$ & & \\
\hline
\end{tabular}

$a: \mathrm{R}=\mathrm{CH}_{3}, \mathrm{C}_{2}$ to $\mathrm{C}_{5} ; 18$ different $\mathrm{RO}_{2}$ radicals ${ }^{b}: \mathrm{K}=\mathrm{R}_{1} /\left(1+\mathrm{R}_{1} / \mathrm{R}_{2}\right) \mathrm{F}_{c}^{A}$ where $\mathrm{A}=\left(1 /\left(1+\log (\mathrm{R} 1 / \mathrm{R} 2)^{2}\right)\right.$ 
given in Table 4). On the basis of the $\mathrm{k}_{4}$ and $\mathrm{k}_{-4}$ rates we can calculate the $\mathrm{NO}_{2}$ levels at which the $\mathrm{N}_{2} \mathrm{O}_{5}$ concentrations equal those of $\mathrm{NO}_{3}$. The calculated values (Table 3) are significantly higher than the geometric mean value of $0.4 \mathrm{ppbv}$ of $\mathrm{NO}_{2}$ observed during MINOS. Interestingly as shown in Table 3, during the entire period of the MINOS experiment, the typical time for the $\mathrm{NO}_{3}$ conversion to $\mathrm{N}_{2} \mathrm{O}_{5}$ is 3 to 9 times slower than the thermal decomposition of $\mathrm{N}_{2} \mathrm{O}_{5}$ to $\mathrm{NO}_{3}$. Thus, at high temperatures as those observed at Finokalia during the MINOS campaign, $\mathrm{NO}_{3}$ is longer lived than $\mathrm{N}_{2} \mathrm{O}_{5}$ and consequently $\mathrm{N}_{2} \mathrm{O}_{5}$ is less effective as reservoir species for $\mathrm{NO}_{3}$ contrary to what is expected at higher $\mathrm{NO}_{2}$ levels and/or lower temperatures. Indeed, for the measured ranges of $\mathrm{NO}_{2}$ and temperature, the equilibrium ratio $\mathrm{N}_{2} \mathrm{O}_{5} / \mathrm{NO}_{3}$ ranges between 0.02 and below unity with an average value of $0.34( \pm 0.26)$. Only on the 13 August, this pattern is inversed with a $\mathrm{N}_{2} \mathrm{O}_{5} / \mathrm{NO}_{3}$ ratio of 1.52 i.e. exceeding unity. During this particular day the site was influenced both by biomass burning as shown on the black carbon levels (Salisbury et al., 2003) and by subsidence of air masses with low RH. In Fig. 6a we depicted the correlation between $\mathrm{NO}_{3}$ concentrations integrated over $1{ }^{\circ} \mathrm{C}$ increments of temperature. Similar dependency is obtained between the lifetime of $\mathrm{NO}_{3}$ and the temperature (Fig. 6b) indicating $\mathrm{N}_{2} \mathrm{O}_{5}$ loss dominance as observed and discussed by Geyer and Platt (2002).

In addition to temperature, $\mathrm{RH}$ varied by almost a factor of 4.5. Figure $6 \mathrm{c}$ presents both the variation of $\mathrm{NO}_{3}$ radical and that of RH. It is interesting to note that the maximum $\mathrm{NO}_{3}$ mixing ratio of $37 \mathrm{pptv}$ has been observed on 11-12 August 2001 due to thermal dissociation of $\mathrm{N}_{2} \mathrm{O}_{5}$ and low heterogeneous removal when the RH was the lowest and the temperature was the highest observed during the experiment. To illustrate the influence of the relative humidity on $\mathrm{NO}_{3}$ levels, the correlation between $\mathrm{NO}_{3}$ and $\mathrm{RH}$ is presented in Fig. $6 \mathrm{~d}$, with $\mathrm{NO}_{3}$ values integrated every 10 units of RH. A highly significant linear relationship is then observed with $\mathrm{NO}_{3}$ decreasing by almost a factor of 3 when $\mathrm{RH}$ increases from 20 $30 \%$ to $80-90 \%$ indicating the importance of both gas phase reactions of $\mathrm{N}_{2} \mathrm{O}_{5}$ with $\mathrm{H}_{2} \mathrm{O}$ and reactions of $\mathrm{N}_{2} \mathrm{O}_{5}$ on particles since the hygroscopic growth of aerosols increases the surface available for heterogeneous reactions. This is also supported by the very good negative correlation between the lifetime of $\mathrm{NO}_{3}$ and relative humidity shown in Fig. 6e. The lifetime of $\mathrm{N}_{2} \mathrm{O}_{5}$ with respect to the gas phase reactions with water into $\mathrm{HNO}_{3}$ is reduced by a factor of 2 (from 46 to $23 \mathrm{~min}$ ) when relative humidity increases from 35 to $85 \%$, which could partly explain the observed negative correlation of $\mathrm{NO}_{3}$ with relative humidity. However, a much faster removal of $\mathrm{N}_{2} \mathrm{O}_{5}$, probably by heterogeneous reactions, is needed to explain the calculated $\mathrm{NO}_{3}$ lifetime of $1-6 \mathrm{~min}$ shown in Fig. 5c.

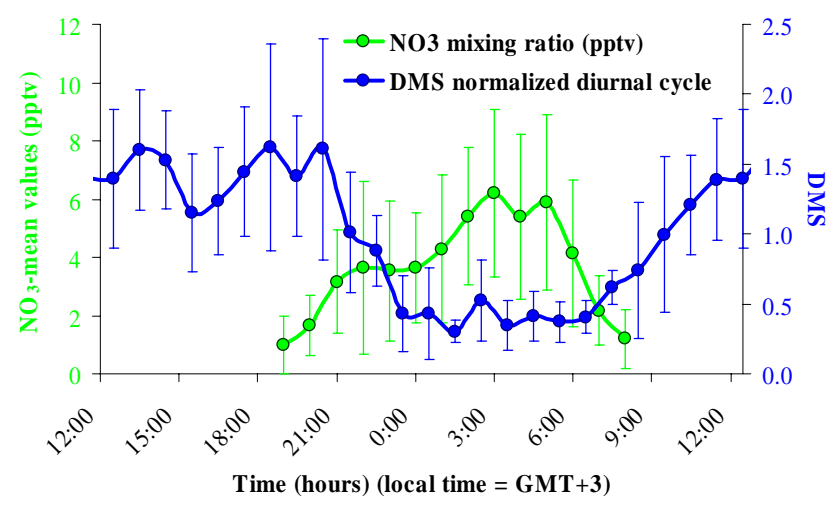

Fig. 7. Diurnal profile of $\mathrm{NO}_{3}$ radical (in pptv) and normalized DMS concentrations (DMS concentrations divided by the corresponding diurnal mean DMS) averaged during the campaign.

\subsection{Impact of DMS and others $\mathrm{VOC}$ on $\mathrm{NO}_{3}$ oxidation}

DMS is the dominant sulfur gas naturally emitted into the atmosphere. It is formed by biological processes in the sea water from dimethylsulfonioprionate (DMSP). The potential role of DMS in the CCN production but also in the acidity of rainwater in remote marine areas has been intensively studied since the publication of the CLAW hypothesis involving the influence of DMS oxidation products on climate (Charlson et al., 1987).

Platt and Le Bras (1997) suggested a potentially important role of DMS in the $\mathrm{NO}_{\mathrm{x}}-\mathrm{NO}_{\mathrm{y}}$ partitioning in the marine background atmosphere. Cantrell et al. (1997) pointed out the contribution of $\mathrm{NO}_{3}$ initiated oxidation of DMS to nighttime $\mathrm{RO}_{2}$ formation. Allan et al. $(1999,2000)$ found that DMS levels can significantly affect the $\mathrm{NO}_{3}$ lifetime. Especially under condition of elevated DMS ( $>100$ pptv), a major fraction of $\mathrm{NO}_{3}$ (up to $90 \%$ ) is removed by reaction with DMS. During MINOS 2001, measurements of DMS were conducted in parallel with the $\mathrm{NO}_{3}$ radical observations. As explained in Sect. 2.1, the $\mathrm{NO}_{3}$ levels measured by the DOAS instrument correspond to a mean value within the first $150 \mathrm{~m}$ a.s.l whereas the DMS measurements have been performed at the sampling site $150 \mathrm{~m}$ a.s.l. However, during most of the campaign, the wind speed was higher than $5 \mathrm{~m} \mathrm{~s}^{-1}$ resulting in a well mixed MBL with height reaching $1000-1500 \mathrm{~m}$ (based on the radiosoundings performed every night at 3:00 LT at the Heraklion airport). Thus with only two exceptions (on the 13 and the 21 August) DMS is expected to be well mixed as has been observed at other marine sites (Davis et al., 1999). It is therefore reasonable to co-investigate the observed $\mathrm{NO}_{3}$ and DMS variations. Figure 7 depicts the mean diurnal variation of $\mathrm{NO}_{3}$ and of normalised DMS during MINOS campaign. The normalised DMS values were derived from the DMS concentrations divided by the corresponding diurnal mean DMS. The use of the normalised DMS values allows representing the diurnal 
Table 5. Heterogeneous reactions taken into account in the model and the corresponding reactive accommodation coefficient $(\gamma ; \mathrm{T}$ : temperature in $\mathrm{K})$. Khet $=\gamma(\mathrm{RT} / 2 \pi \mathrm{M})^{0.5} \mathrm{~A}$, where $M$ is the molecular mass of the compound, $A$ the aerosol surface area and $R$ the gas constant. $\gamma$ values are taken from Atkinson et al. (2003) (IUPAC recommendations web version 2003).

*close to the upper limit for the reaction.

\begin{tabular}{ccc}
\hline & Reaction & $\gamma$ \\
\hline Khet $\mathrm{NO}_{3}$ & $\mathrm{NO}_{3(\mathrm{~g})} \rightarrow \mathrm{NO}_{3}$ (part) & 0.006 \\
Khet $\mathrm{NO}_{3}$ & $\mathrm{NO}_{3(\mathrm{~g})} \rightarrow \mathrm{HNO}_{3}(\mathrm{~g})$ & $2 . \times 10^{-4}$ \\
Khet $\mathrm{N}_{2} \mathrm{O}_{5}$ & $\mathrm{~N}_{2} \mathrm{O}_{5(\mathrm{~g})} \rightarrow \mathrm{NO}_{3}$ (part) & $0.1^{*}$ \\
Khet $\mathrm{HNO}_{3}$ & $\mathrm{HNO}_{3(\mathrm{~g})} \rightarrow \mathrm{NO}_{3 \text { (part })}$ & 0.0014 \\
Khet $\mathrm{HO}_{2}$ & $\mathrm{HO}_{2(\mathrm{~g})} \rightarrow$ loss & $5.66 \times 10^{-5} \exp (1560 / \mathrm{T})$ \\
\hline
\end{tabular}

variation of the compound eliminating its day-to-day variability. Within about $3 \mathrm{~h}$ during and after sunset DMS decreases by a factor of about 6 when $\mathrm{NO}_{3}$ radicals build up. This DMS decrease is due to both DMS oxidation by $\mathrm{NO}_{3}$ leading to $\mathrm{HNO}_{3}$ and dilution by continental air resulting to about 30\% lower DMS fluxes during night (Bardouki et al., 2003a). Such a diurnal variation was observed during the entire campaign, and more details are reported in a companion paper (Bardouki et al., 2003). On the basis of the observed average $\mathrm{NO}_{3}, \mathrm{OH}$ and DMS levels, DMS nighttime oxidation by $\mathrm{NO}_{3}$ is about $75 \%$ the daytime loss by reaction with $\mathrm{OH}$ radicals. This is determined in further detail in Kanakidou et al. (2004, paper in preparation).

By considering the observed mean DMS concentration of 30 pptv during the campaign a lifetime of about $10^{3} \mathrm{~s}$ is estimated for $\mathrm{NO}_{3}$ radicals, which is significantly longer by almost a factor of 5-10 than that calculated during the campaign and depicted in Fig. $5 \mathrm{c} . \mathrm{NO}_{3}$ radicals can also be removed by a variety of VOCs especially by isoprene and terpenes. During the campaign isoprene levels were very low (about 7 pptv; Gros et al., 2003). No terpenes were measured during the campaign but their levels are expected to be very low since the surrounding vegetation is sparse and consists mainly of some dry herbs and low bushes. These results indicate that in Finokalia gas-phase reactions of DMS and most probably other VOCs with $\mathrm{NO}_{3}$ radicals play a relatively minor role in the $\mathrm{NO}_{3}$ budget and that most $\mathrm{NO}_{3}$ is removed from the atmosphere via reactions of $\mathrm{N}_{2} \mathrm{O}_{5}$ with water vapour and/or $\mathrm{NO}_{3}$ and $\mathrm{N}_{2} \mathrm{O}_{5}$ on aerosol surfaces.

\subsection{Impact of $\mathrm{NO}_{3}$ on $\mathrm{HNO}_{3}$ formation}

To investigate the $\mathrm{NO}_{3}$ budget and to evaluate the $\mathrm{NO}_{3}$ involvement in $\mathrm{HNO}_{3}$ formation, box model simulations have been performed.

\subsubsection{The model}

The chemical scheme used for this purpose is based on Poisson et al. (2001) as updated by Tsigaridis and Kanakidou (2002) for the inorganic and hydrocarbon chemistry (up to $\mathrm{C}_{5}$ ) including $\mathrm{NO}_{3}$ radical reactions with peroxy radicals. Reaction rates have been updated according to Atkinson et al. (2003) (IUPAC-web version 2003) recommendations. Table 4 presents the gas phase reactions of $\mathrm{NO}_{3}$ considered in the model. The $\mathrm{N}_{2} \mathrm{O}_{5}$ gas phase reactions with $\mathrm{H}_{2} \mathrm{O}$ ( 1 and 2 order with respect to $\mathrm{H}_{2} \mathrm{O}$, Reaction $5 \mathrm{a}$ and b) are also considered as well as the heterogeneous reactions of $\mathrm{NO}_{3}$, $\mathrm{N}_{2} \mathrm{O}_{5}$ and $\mathrm{HNO}_{3}$ listed in Table 5. The sensitivity of the $\mathrm{NO}_{3}$ calculated levels to the rates of the Reactions (5a) and (5b) has been studied on the basis of the IUPAC (Atkinson et al., 2003) and of the upper and lower limit JPL (Sander et al. 2003) recommendations. It has been found that the reported uncertainty in these rates can lead to up to a $0.5 \mathrm{pptv}$ of uncertainty in the $\mathrm{NO}_{3}$ calculated levels. Larger uncertainty is expected to be linked with the temperature dependence of these rates (up to $1.2 \mathrm{pptv}$ ) that is unfortunately not sufficiently documented (Dimitroulopoulou and Marsh, 1997). Deposition of $\mathrm{HNO}_{3}, \mathrm{NO}_{3}, \mathrm{~N}_{2} \mathrm{O}_{5}$ and $\mathrm{NO}_{3}^{-}$(particulate) onto surfaces has been considered with deposition velocities of $1 \mathrm{~cm} \mathrm{~s}^{-1}$ for the gases and 3 times higher for the particles since most $\mathrm{NO}_{3 \text { (part) }}^{-}$is on coarse sea-salt particles (Bardouki et al., 2003b).

Observed hourly mean values of $\mathrm{O}_{3}$, photolysis rates of $\mathrm{NO}_{2}\left(\mathrm{JNO}_{2}\right)$ and $\mathrm{O}_{3}\left(\mathrm{JO}^{1} \mathrm{D}\right)$ and $\mathrm{CO}$ are used as input to the model that was also forced every 5 -min by the geometric hourly mean values of $\mathrm{NO}_{2}$ measured by the DOAS instrument. Missing $\mathrm{NO}_{2}$ data have been substituted by extrapolating the observations on the basis of the diurnal mean normalized profile of $\mathrm{NO}_{2}$ measured during the campaign. Isoprene, ethene, propene, formaldehyde, acetaldehyde, ethane, propane and butane mixing ratios are kept equal to 7, 100, $50,1000,100,1000,260$ and 120 pptv respectively, according to observations during the MINOS campaign (Gros et al., 2003) and in the West Mediterranean (Plass-Dümler et al., 1992). Aerosol surfaces observed during the campaign (Bardouki et al., 2003a) are used to calculate the heterogeneous removal rates for the reactions listed in Table 5. Diurnal mean DMS observations were used to account for the DMS emitted by the ocean and its impact on $\mathrm{NO}_{3}$ chemistry in the marine boundary layer. DMS oxidation both by $\mathrm{OH}$ radical and by $\mathrm{NO}_{3}$ radical is taken into account (see reaction rates in Table 4). Initial concentrations of hydrogen peroxide (495 pptv), methane (1.8 ppmv) and particulate nitrate $\left(25 \mathrm{nmol} \mathrm{m}^{-3}\right)$ are applied.

\subsubsection{Model results}

Note that since hourly mean data are used as input to the model for most species, our simulations are not expected to provide reliable higher time resolution variability. The model 


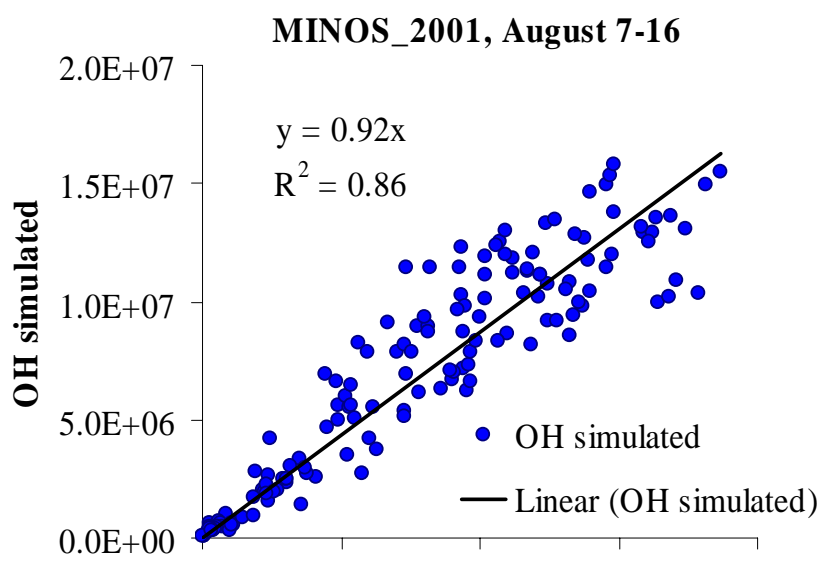

$\begin{array}{lllll}0.0 \mathrm{E}+00 & 5.0 \mathrm{E}+06 & 1.0 \mathrm{E}+07 & 1.5 \mathrm{E}+07 & 2.0 \mathrm{E}+07\end{array}$

OH observed

Fig. 8. Correlation between the modelled and measured $\mathrm{OH}$ concentrations during the campaign.

satisfactorily simulates the daytime variation and the absolute concentrations of $\mathrm{OH}$ radicals as shown in Fig. 8, although overall it underestimates the observations of $\mathrm{OH}$ radical by about $8 \%$. Details of $\mathrm{OH}$ radical measurements are reported by Berresheim et al. (2003).

$\mathrm{NO}_{3}$ model versus observations. $\mathrm{NO}_{3}$ radical concentrations simulated by the model for the whole period are shown in Fig. 9 together with the observed $\mathrm{NO}_{3}$ values (hourly mean). When neglecting the $\mathrm{NO}_{3}$ values observed during the nights of 11 to 12 and 12 to 13 of August 2001 that are exceptionally high for the measuring period the model results seem to capture the order of magnitude of the observations within the range of their variability. Note that during these days biomass burning activities have affected the site as indicated by the $\mathrm{CO}$ observed levels and relevant compounds (Salisbury et al., 2003). In addition, the very low RH observed on the 8 and the 13 August and linked to low aerosol surfaces (Bardouki et al., 2003a) indicates subsidence of air masses from higher altitudes. This transport mechanism can not be reproduced by the box model. Although, the mean $\mathrm{NO}_{3}$ concentration of $4.5 \mathrm{pptv}$ (all data) observed during night is in quite good agreement with the $4.7 \mathrm{pptv}$ simulated by the model for the same period, there is no statistically significant correlation between the hourly averaged observed concentrations and the hourly calculated $\mathrm{NO}_{3}$

Losses of $\mathrm{NO}_{3}$. According to our calculations photolysis of $\mathrm{NO}_{3}$ is by far the major loss mechanism during daytime since it accounts for more than half the total removal of $\mathrm{NO}_{3}$ and $\mathrm{N}_{2} \mathrm{O}_{5}$. The loss of $\mathrm{NO}_{3}$ by the reaction with $\mathrm{NO}$ is half that due to photolysis. During night the relative importance of the various paths of $\mathrm{NO}_{3}$ and $\mathrm{N}_{2} \mathrm{O}_{5}$ loss is changing but generally $\mathrm{N}_{2} \mathrm{O}_{5}$ heterogeneous and gas phase losses (to molecules other than $\mathrm{NO}_{3}$ ) are almost a factor of 2 higher than the reaction of $\mathrm{NO}_{3}$ with DMS. This relatively small

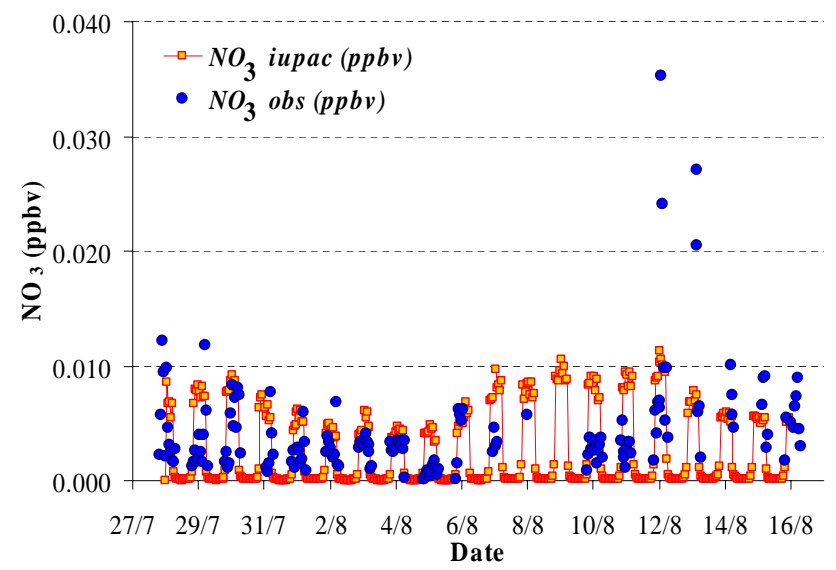

Fig. 9. Comparison between the modelled (orange line) and measured $\mathrm{NO}_{3}$ (closed circles) hourly mean levels (in ppbv) during the campaign.

contribution of DMS to $\mathrm{NO}_{3}$ loss (less than $25 \%$ ) compared to earlier published estimates by Carslaw et al. (1997) reflects the different conditions encountered during the studies with regard to the DMS levels (the lowest have been observed during MINOS) and the different durations of nighttime, when this reaction is important (shortest during our study). Under the studied conditions the reactions of other VOCs with $\mathrm{NO}_{3}$ seem to be of minor importance in controlling the $\mathrm{NO}_{3}$ budget.

$\mathrm{HNO}_{3}$ and $\mathrm{NO}_{3}^{-}$(particulate) model versus observations. The contribution of $\mathrm{NO}_{3}$ nighttime reactions with VOC (including DMS), leading to $\mathrm{HNO}_{3}$ formation has also been investigated on the basis of the model results. The model simulates within $10 \%$ the observed levels of the sum of the gaseous $\mathrm{HNO}_{3}$ and the particulate $\mathrm{NO}_{3}^{-}\left(\mathrm{NO}_{3}\right.$ (part) $)$. The best agreement is achieved for the period 28 July to 1 August 2001 (Fig. 10a). Thus, to investigate the $\mathrm{NO}_{3}$ involvement in the $\mathrm{HNO}_{3}$ production, we focus on this first period of the campaign when the model appears to realistically simulate $\mathrm{HNO}_{3}$ levels.

According to our calculations $\mathrm{HNO}_{3}$ is predominantly formed during daytime by reaction of $\mathrm{NO}_{2}$ with $\mathrm{OH}$ at a rate of $1.12 \mathrm{ppbv} / \mathrm{d}$. DMS oxidation by $\mathrm{NO}_{3}$ radicals is an important source of $\mathrm{HNO}_{3}$ during night, producing $0.11 \mathrm{ppbv} / \mathrm{d}$ of $\mathrm{HNO}_{3}$ whereas $0.10 \mathrm{ppbv} / \mathrm{d}$ of $\mathrm{HNO}_{3}$ is formed from the gas phase reactions of $\mathrm{N}_{2} \mathrm{O}_{5}$ with water vapour. The $\mathrm{NO}_{3}$ heterogeneous reaction appears to be minor since it does not produce more than $1 \mathrm{pptv} / \mathrm{d}$ of $\mathrm{HNO}_{3}$. The overall $\mathrm{HNO}_{3}$ production is calculated to be $1.3 \mathrm{ppbv} / \mathrm{d}$. $\mathrm{NO}_{3}$ and $\mathrm{N}_{2} \mathrm{O}_{5}$ gas phase reactions constitute the nighttime chemical source for $\mathrm{HNO}_{3}$ and contribute therefore approximately $16 \%$ to the $\mathrm{HNO}_{3}$ production (Fig. 10b). Under the studied conditions, the reactions of $\mathrm{NO}_{3}$ with aldehydes are minor for $\mathrm{HNO}_{3}$ production since only 3 and $1 \mathrm{pptv} / \mathrm{d}$ are produced during the $\mathrm{NO}_{3}$ initiated oxidation of formaldehyde 

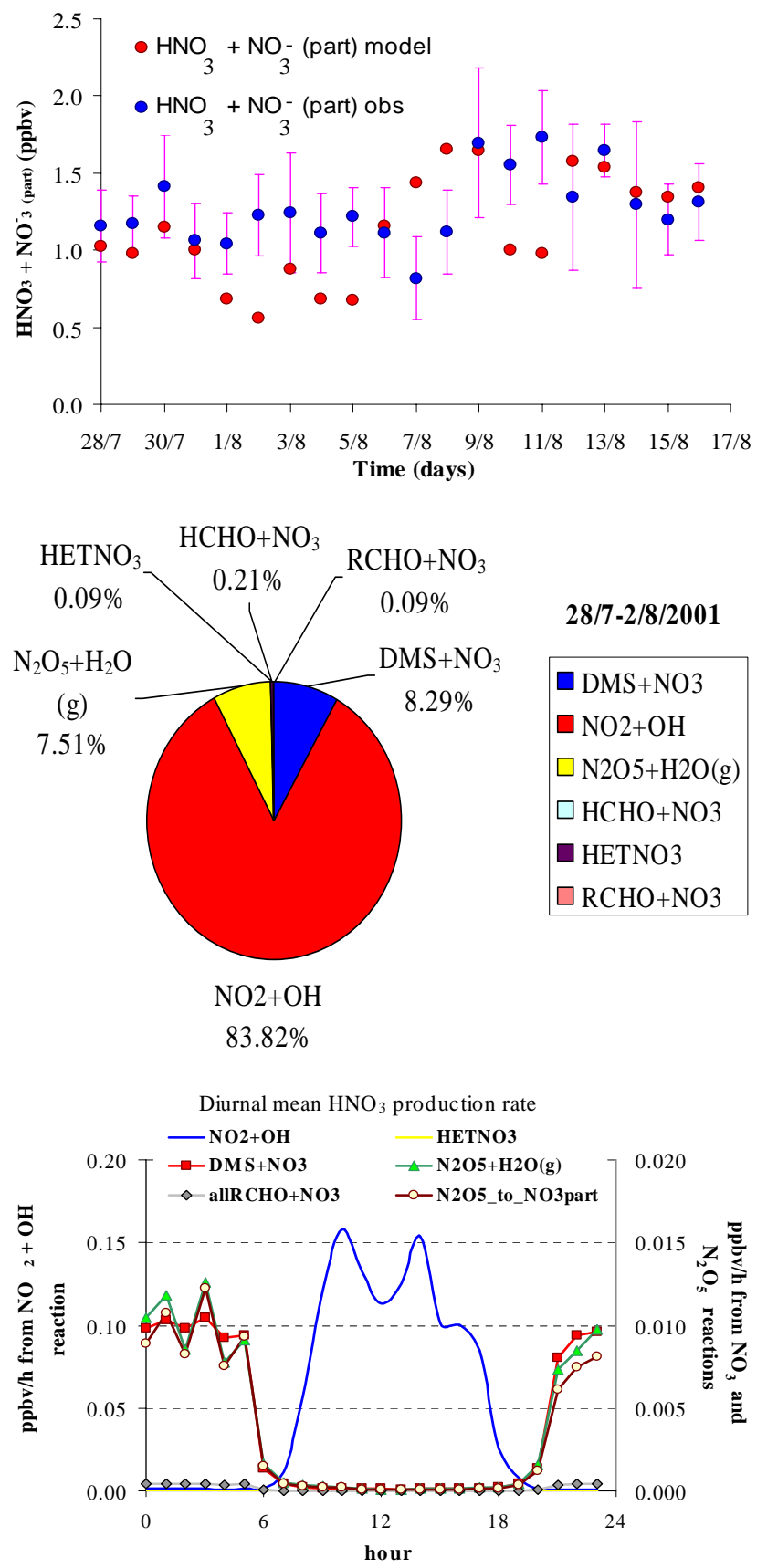

Fig. 10. (a) Comparison between the calculated and observed sum

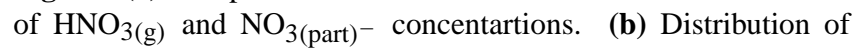
$\mathrm{HNO}_{3}$ (gaseous) formation; (c) diurnal mean $\mathrm{HNO}_{3}$ production rate. Note the difference of a factor of 10 in the scale for the $\mathrm{NO}_{2}+\mathrm{OH}$ reaction rate (axis to the left) compared to the other reactions (axis to the right).

and higher aldehydes respectively. Figure 10c depicts the mean diurnal variation of the $\mathrm{HNO}_{3}$ production rates, which reveals the importance of the $\mathrm{NO}_{3}$ and $\mathrm{N}_{2} \mathrm{O}_{5}$ reaction for $\mathrm{HNO}_{3}$ formation during nighttime.
The calculated $\mathrm{HNO}_{3}$ daytime production rate of $1.12 \mathrm{ppbv} / \mathrm{d}$ during the MINOS campaign is more than double that suggested by Carslaw et al. (1997) for lower photochemical activity conditions (less $\mathrm{OH}$ radicals than during MINOS). However, the DMS contribution to $\mathrm{HNO}_{3}$ formation via $\mathrm{H}$-abstraction by $\mathrm{NO}_{3}$ radicals is lower than the estimate by Carslaw et al. (1997). This difference is due to high DMS concentrations that resulted from a phytoplankton bloom in the area studied by these authors. Thus our results, although different from those in that earlier study, are fully consistent when taking into account the different conditions of the studied environments.

The heterogeneous reaction of $\mathrm{N}_{2} \mathrm{O}_{5}(\gamma=0.1)$ on particles does not produce more than $0.09 \mathrm{ppbv} / \mathrm{d}$ of particulate $\mathrm{NO}_{3}^{-}\left(\mathrm{NO}_{3 \text { (part) }}^{-}\right)$. Therefore, by considering the overall $\mathrm{HNO}_{3(g)}+\mathrm{NO}_{3 \text { (part) }}^{-}$production, $\mathrm{N}_{2} \mathrm{O}_{5}$ and $\mathrm{NO}_{3}$ reactions contribute up to $21 \%$, whereas the remaining is attributed to the $\mathrm{NO}_{2}$ reaction with $\mathrm{OH}$ during daytime.

With regard to $\mathrm{HNO}_{3}$ loss from the atmosphere, reaction with $\mathrm{OH}$ and photolysis are calculated to play only a minor role in the total loss of $\mathrm{HNO}_{3}$ (2\% and $1 \%$ respectively) whereas its main removal mechanism $(97 \%)$ is conversion to particulate $\mathrm{NO}_{3}^{-}$and subsequent deposition.

\section{Conclusions}

During the MINOS campaign from 27 July to 17 August 2001, a complete set of $\mathrm{NO}_{3}$ data was obtained by a DOAS instrument with $\mathrm{NO}_{3}$ levels that vary from the detection limit up to 37 pptv. The 24-hour mean $\mathrm{NO}_{3}$ levels were a factor of 12 higher than these of the $\mathrm{OH}$ radical. Thus for some compounds such as DMS, the nighttime destruction by $\mathrm{NO}_{3}$ is much more important than by $\mathrm{OH}$ during daylight. The role of $\mathrm{NO}_{3}$ for the overall oxidation efficiency of the Mediterranean atmosphere on a yearly basis is a topic for further research since preliminary measurements show a much smaller seasonal variation for $\mathrm{NO}_{3}$ compared to $\mathrm{OH}$ radicals.

The calculated lifetime of $\mathrm{NO}_{3}$ during the MINOS campaign range between 1 and $6 \mathrm{~min}$, supporting the assumption of steady state conditions between production and destruction of $\mathrm{NO}_{3}$. Gas-phase reactions of DMS and other VOCs with $\mathrm{NO}_{3}$ radicals appear to play a minor role in the $\mathrm{NO}_{3}$ budget, since the major fraction of $\mathrm{NO}_{3}$ is removed from the atmosphere via $\mathrm{N}_{2} \mathrm{O}_{5}$ reactions.

$\mathrm{NO}_{3}$ radical as well as its lifetime was found to be strongly anti-correlated with the relative humidity $(\mathrm{RH})$. High values of $\mathrm{RH}$ are associated with efficient loss of $\mathrm{NO}_{3}$, reducing it to levels down to the detection limit. This indicates that both gas phase reactions of $\mathrm{N}_{2} \mathrm{O}_{5}$ with $\mathrm{H}_{2} \mathrm{O}$ and reactions of $\mathrm{NO}_{3}$ and $\mathrm{N}_{2} \mathrm{O}_{5}$ on particles are important since the hygroscopic growth of aerosols increases the surface available for heterogeneous reactions.

$\mathrm{N}_{2} \mathrm{O}_{5}$ and $\mathrm{NO}_{3}$ reactions contribute up to $21 \%$ to the total formation rate of $\mathrm{HNO}_{3(\mathrm{~g})}+\mathrm{NO}_{3 \text { (part) }}^{-}$, while the remaining 
and thus major part is attributed to the $\mathrm{NO}_{2}$ reaction with $\mathrm{OH}$ during daytime. The contribution of $\mathrm{N}_{2} \mathrm{O}_{5}$ and $\mathrm{NO}_{3}$ reactions to the overall $\mathrm{HNO}_{3(\mathrm{~g})}+\mathrm{NO}_{3 \text { (part) }}^{-}$production on a seasonal basis deserves further study.

Acknowledgements. We wish to thank T. Klupfel for assistance with the DOAS instrument, M. Martinez-Harder for useful comments on DOAS measurements, H. Bardouki, V. Gros, G. Kouvarakis, K. Oikonomou and J. Sciare for communicating the DMS, $\mathrm{HNO}_{3}, \mathrm{NO}_{3 \text { (part) }}^{-}$and VOC data prior publication, Prof. U. Platt for helpful discussions, the Greek secretary of research and Technology for financial support of M. Vrekoussis (PENED grant) and the two anonymous reviewers for their fruitful remarks. M. Vrekoussis acknowledges support by DAAD for educational visits to MPI-Mainz.

\section{References}

Allan, B. J., Carslaw, N., Coe, H., Burgess, R., and Plane, J. M. C.: Observations of the Nitrate Radical in the marine boundary layer, J. Atmos. Chem., 33, 129-154, 1999.

Allan, B. J., Mc Figgans, G., Plane, J. M. C., Coe, H. and Mc Fadyen, G. G.: The nitrate radical in the remote marine boundary layer, J. Geophys.Res., 105, D19, 24 191-24 204, 2000.

Atkinson, R.: Kinetic and mechanism of gas-phase reactions of $\mathrm{NO}_{3}$ radical with organic compounds, J. Physical Chem., 20, 459-507, 1991.

Atkinson, R., Baulch, D. L., Cox, R. A., Crowley, J. N., Hampson, R. F., Kerr, J. A., Rossi, M. J., and Troe, J.: IUPAC recommendations, Web version: http://www.iupac-kinetic.ch.cam.ac.uk/, 2003.

Bardouki, H., Berresheim, H., Vrekoussis, M., Sciare, J., Kouvarakis, G., Oikonomou, C., Schneider, J., and Mihalopoulos, N.: Gaseous (DMS, DMSO, $\mathrm{SO}_{2}, \mathrm{H}_{2} \mathrm{SO}_{4}, \mathrm{MSA}$ ) and particulate $\left(\mathrm{MS}^{-}\right.$and $\mathrm{SO}_{4}^{2-}$ ) sulfur compounds during the MINOS campaign, Atmos. Chem. Phys., 3, 1871-1886, 2003a.

Bardouki, H., Liakakou, H., Economou, C., Sciare, J., Smolik, J., Zdimal, V., Eleftheriadis, K., Lazaridis, M., Dye, C., and Mihalopoulos, N.: Chemical composition of size-resolved atmospheric aerosols in the eastern Mediterranean during summer and winter, Atmos. Environ., 37, 195-208, 2003b.

Berresheim, H., Elste, T., Plass-Dülmer, C., Eisele, F. L., and Tanner, D. J.: Chemical ionization mass spectrometer for long-term measurements of atmospheric $\mathrm{OH}$ and $\mathrm{H}_{2} \mathrm{SO}_{4}$, Int. J. Mass Spectrom., 202, 91-103, 2000.

Berresheim, H., Plass-Dülmer, C., Elste, T., Mihalopoulos, N., and Rohrer, F.: $\mathrm{OH}$ in the coastal boundary layer of Crete during MINOS: Measurements and relationship with ozone photolysis, Atmos. Chem. Phys., 3, 639-649, 2003.

Brauers, T., Hausmann, M., Brandenburger, U., and Dorn, H.-P.: Improvement of Differential Optical Spectroscopy with a multichannel scanning technique, Appl. Opt., 34, 4472-4479, 1995.

Cantrell, C. A., Shetter, R. E., Calvert, J. G., Eisele, Fl., and Tanner, D. J.: Some considerations of the origin of nighttime peroxy radicals observed in MILOPEX 2c, J. Geophys. Res., 102, 15 899-15 913, 1996.

Carslaw, N., Plane, J. M. C., Coe, H., and Cuevas, E.: Observation of the nitrate radical in the free troposphere., J. Geophys.Res., 102, D9, 10613-10622, 1997.
Charlson, R. J., Lovelock, J. E., Andreae, M. O., and Warren, S G.: Oceanic phytoplankton, atmospheric sulphur, cloud albedo and climate: a geophysiological feedback, Nature, 326, 655$661,1987$.

Cofer III, W. R., Collins, V. G., and Talbot, R. W.: An improved aqueous scrubber for the collection of soluble atmospheric trace gases, Environ. Science Technology, 19, 557-560, 1985.

Davis, D., Chen, G., Bandy, A., Thornton, D., Eisele, F., Mauldin, L., Tanner, D., Lenschow, D., Fuelberg, H., Huebert, B., Heath, J., Clarke, A., and Blake, D.: Dimethyl sulfide oxidation in the equatorial Pacific: Comparison of model simulations with field observations for DMS, $\mathrm{SO}_{2}, \mathrm{H}_{2} \mathrm{SO}_{4(\mathrm{~g})}, \mathrm{MSA}_{(\mathrm{g})}$, and $\mathrm{MS}$, and NSS, J. Geophys. Res., 104, 5765-5784, 1999.

DeMore, W. B., Sander, S. P., Golden, D. M., Hampson, R. F., Kyrylo, M. J., Howard, C. J., Ravishankara, A. R., Kolb, C. E., and Molina, M. J.: Chemical kinetics and photochemical data for use in stratospheric modeling, Eval. 11, Jet Propul. Lab., Pasadena, Calif., 1997.

Dimitroulopoulou, C. and Marsh, A. R. W.: Modelling studies of $\mathrm{NO}_{3}$ nighttime chemistry and its effects on subsequent ozone formation, Atmos. Environ., 31, 3041-3057, 1997.

Geyer, A., Ackermann, R., Dubois, R., Lohrmann, B., Muller, T., and Platt, U.: Long term observation of Nitrate radicals in the continental layer near Berlin., Atmos. Environ., 35, 3619-3631, 2001.

Geyer, A. and Platt, U.: Temperature dependence of the $\mathrm{NO}_{3}$ loss frequency: A new indicator for the contribution of $\mathrm{NO}_{3}$ to the oxidation of monoterpenes and $\mathrm{NO}_{\mathrm{x}}$ removal in the atmosphere, J. Geophys. Res., 107, D20, 4431, doi:10.1029/2001JD001215, 2002.

Gros, V., Williams, J., van Aardenne, J. A, Salisbury, G., Hofmann, R., Lawrence, M. G., von Kuhlmann, R., Lelieveld, J., Krol, M., Berresheim, H., Lobert, J. M., and Atlas, E.: Origin of anthropogenic hydrocarbons and halocarbons measured in the summertime european outflow (on Crete in 2001) Atmos. Chem. Phys., 3, 1223-1235, 2003.

Heintz, F., Platt, U., Flentje, H., and Dubois, R.: Long term observation of Nitrate radicals at the Tor Stations, Kap Arkona (Rügen), J. Geophys. Res., 101, D17, 22 891-22 910, 1996.

Kouvarakis, G. and Mihalopoulos, N.: Seasonal variation of dimethylsulfide in the gas phase and of methanesulfonate and non-sea-salt sulfate in the aerosol phase measured in the eastern Mediterranean atmosphere, Atmos. Environ., 36, 929-938, 2002.

Martinez, M., Perner, D., Hackenthal, E., Kultzer, S., and Schultz, L.: $\mathrm{NO}_{3}$ at Helgoland during the NORDEX campaign in October 1996, J. Geophys. Res., 105, D18, 22 685-22 695, 2000.

Martinez-Harder, M.: Messungen von BrO und anderen Spurenstoffen in der bodennahen Troposphare, Ph.D Thesis, Max PlanckInstitute for Chemistry, Mainz, 1998.

Mentel, Th. F., Bleilebens, D., and Wahner, A.: A study of nighttime nitrogen oxide oxidation in large reaction chamber - The fate of $\mathrm{NO}_{2}, \mathrm{~N}_{2} \mathrm{O}_{5}, \mathrm{HNO}_{3}$ and $\mathrm{O}_{3}$ at different humidities, Atmos. Environ, 30, 23, 4007-4020, 1996.

Platt, U. and Le Bras, G.: Influence of DMS on the $\mathrm{NO}_{x}-\mathrm{NO}_{y}$ partitioning and the $\mathrm{NO}_{\mathrm{x}}$ distribution in the marine backgraound atmosphere, Geophys. Res. Letters, 24, 1935-1938, 1997.

Platt, U., Winer, A. M., Biermann, H. W., Atkinson, R., and Pitts, J.: Measurements of nitrate radical concentrations in continental air, Environ. Science Technology, 18, 365-369, 1984. 
Platt, U., Perner, D., Harris, G. W., Winer, A. M., and Pitts, J. M.: Detection of $\mathrm{NO}_{3}$ in the polluted troposphere by differential optical absorption, Geophys. Res. Letters, 7, 89-92, 1980.

Plass-Dümler, C., Ratte, M., Koppmann, R., and Rudolph, J.: C2C9 Hydrocarbons in the Marine atmosphere during NATAC 91, paper presented at the NATAC 91 workshop, Odessa, Ukraine, 1992.

Poisson, N., Kanakidou, M., Bonsang, B., Behmann, T., Burrows, J. P., Fischer, H., Golz, C., Harder, H., Lewis, A., Moortgat, G. K., Nunes, T., Pio, C. A., Platt, U., Sauer, F., Schuster, G., Seakins, P., Senzig, J., Seuwen, R., Trapp, D., Volz-Thomas, A., Zenker, T., and Zitzelberger, R.: The impact of natural non-methane hydrocarbon oxidation on the free radical and ozone budgets above a eucalyptus forest, Chemosphere: Global Change Science, Elsevier Science, 3, 353-366, 2001.

Salisbury, G., Williams, J., Holzinger, R., Gros, V., Mihalopoulos, N., Vrekoussis, M., Sarda-Estève, R., Berresheim, H., von Kuhlmann, R., Lawrence, M., and Lelieveld, J.: Ground-based PTR-MS measurements of reactive organic compounds during the MINOS campaign in Crete, July-August 2001, Atmos. Chem. Phys. 3, 925-940, 2003.

Sander, S. P., Friedl, R. R., Ravishankara, A. R., Golden, D. M., Kolb, C. E., Kurylo, M. J., Huie, R. E., Orkin, V. L., Molina, M. J., Moortgat, G. K., and Finlayson-Pitts, B. J.: Chemical Kinetics and Photochemical Data for Use in Atmospheric Studies, Evaluation Number 14, JPL, Publication 02-25, February 2003.

Sciare, J. and Mihalopoulos, N.: Atmospheric Dimethylsulfoxide (DMSO): An improved method for Sampling and analysis. Atmos. Environ., 34, 151-156, 2000.
Sverdrup, G. M., Spicer, C. W., and Ward, G. F.: Investigation of the gas-phase reaction of dinitrogen pentoxide with water-vapor, Int. J. Chem. Kinet., 19, 191-205, 1987.

Tsigaridis, K. and Kanakidou, M.: Importance of Volatile Organic Compounds Photochemistry Over a Forested Area in Central Greece, Atmos.Environ., 36, 19, 3137-3146, 2002.

Wahner, A., Mentel, T. F., and Sohn, M.: Gas-phase reaction of $\mathrm{N}_{2} \mathrm{O}_{5}$ with water vapour: importance of heterogeneous hydrolysis of $\mathrm{N}_{2} \mathrm{O}_{5}$ and surface deposition of $\mathrm{HNO}_{3}$ in a large Teflon chamber, Geophys. Res. Letters, 25, 2169-2172, 1998a.

Waengberg, I., Etzkorn, T., Barnes, I., Platt U., and Becker, $\mathrm{K}$.: Absolute determination of the temperature behavior of the $\mathrm{NO}_{2}+\mathrm{NO}_{3}^{-}+(\mathrm{M}) \rightarrow \mathrm{N}_{2} \mathrm{O}_{5}+(\mathrm{M})$ equilibrium, J. Phys. Chem. A, 101, 9694-9698, 1997.

Wayne, R. P., Barnes, I., Biggs, P., Burrows, J. P., Canasa-Mas, C. E., Hjorth, J., Le Bras, G., Moorgat, G. K., Perner, D., Poulet, G., Restelli, G., and Sidebottom, H.: The nitrate radical physics, chemistry, and the atmosphere., Atmos. Environ., 25A, 1-203, 1991.

Yokelson, R. J., Burkholder, J. B., Fox, R. W., Talukdar, R. K., and Ravisankara, A. R.: Temperature dependence of the $\mathrm{NO}_{3}$ radical, J. Phys. Chem. 98, 13 144-13 150, 1994.

Yoshino, K., Esmond., J. R., and Parkinson, W. H.: High resolution absorption cross section measurements of $\mathrm{NO}_{2}$ in the UV and VIS region, Chemical Physics, 221, 169-174, 1997.

Yvon, S. A., Plane, J. M. C., Nien, C.-F., Cooper, D. J., and Saltzman, E. S.: Interaction between nitrogen and sulphur cycles in the polluted marine boundary layer, J. Geophys. Res., 101, 3, 1379-1386, 1996. 